\title{
Iceland's external affairs in the Middle Ages: The shelter of Norwegian sea power
}

\author{
Baldur Pórhallsson, Professor of Political Science, University of Iceland
}

\begin{abstract}
According to the international relations literature, small countries need to form an alliance with larger neighbours in order to defend themselves and be economically sustainable. This paper applies the assumption that small states need economic and political shelter in order to prosper, economically and politically, to the case of Iceland, in an historical context. It analyses whether or not Iceland, as a small entity/country in the Middle Ages (from the Settlement in the $9^{\text {th }}$ and $10^{\text {th }}$ centuries until the late $14^{\text {th }}$ century) enjoyed political and economic shelter provided by its neighbouring states. Admitting that societies were generally much more self-sufficient in the Middle Ages than in our times, the paper argues that Iceland enjoyed essential economic shelter from Norwegian sea power, particularly as regards its role in securing external market access. On the other hand, the transfer of formal political authority from Iceland to the Norwegian crown was the political price paid for this shelter, though the Icelandic domestic elite, at the time, may have regarded it as a political cover. The country's peripheral location shielded it both from military attacks from outsiders and the king's day-to-day interference in domestic affairs. That said, the island was not at all unexposed to political and social developments in the British Isles and on the European continent, e.g. as regards the conversion to Christianity and the formation of dynastic and larger states. This paper claims that the analysis of the need for shelter needs to take into account the political and economical costs that may be involved in a shield. Also, it needs to address how external actors may solve the problem of internal order. Moreover, an analysis from the point of view of the advantages of political or military shelter needs to address the importance of the extent of engagement of a small community, particularly a remote one, with the outside world. The level of engagement and the identity of the entity with which reciprocal transactions take place may have an important bearing on the community. This was the case in Iceland, i.e. communication with the outside world was of immense importance during the Middle Ages. Hence, the paper suggests that an analysis of the means by which shelter was secured must address the importance of communication according to the centre-periphery relations model.
\end{abstract}




\section{STJÓRNSÝSLA}

Keywords: Iceland, small states, international relations, shelter, Middle Ages, Norway.

\section{Introduction}

The main aim of this paper is to test the case of Iceland within the framework of smallstate theory and answer its key consideration by examining whether Iceland, as a small entity/country, had external shelter or stood on its own during the Middle Ages. The history of Iceland is, almost without exception, told through the geographical location of the executive branch of government and accordingly split into eras of external or domestic rule. The most important element is whether political power was located in the country or in its neighbouring states, i.e. Norway and Denmark (For instance, see Aðils 1915; Jónsson 1989; Karlsson 1985; Karlsson 2000). Normally, the story begins with the Settlement by the independent and brave Viking explorers (Björnsson et al. 2008) and the establishment of the Althingi (the entity's parliament) in around 930, which is interpreted as marking the creation of the Icelandic Commonwealth, the 'nation's' most glorious era. The Commonwealth then comes to a halt with 'the fateful decision' to include the country in the Norwegian monarchy in 1262. This 'tragic decision' was taken after a period of domestic political violence on an unprecedented scale which coincided with pressure by the Norwegian king on leading chieftains and farmers in Iceland to submit to his rule. The traditional historical narrative states that submission to foreign authority led to catastrophic economic and political decline of the country which lasted for centuries (Aðils 1903; Jónsson 1915-16). An end was not put to the suffering of the Icelandic nation until it reclaimed its independence (Björnsson et al. 2008), according to this narrative. The change of fortune is seen as manifested in the rapid economic development of the country in the first half of the $20^{\text {th }}$ century: a result of greater independence from Denmark, i.e. Home Rule in 1904, Sovereignty in 1918 and the creation of the Republic in 1944 (for a good overview of this narrative, see Hálfdanarson 2001a). Iceland's history was often analysed as 'a specific isolated phenomenon' ripped out of the context of world history (Agnarsdóttir 1995, 69).

On the other hand, some historians have categorized Iceland's history according to trade and external relations. They refer to the period from 1262 until 1400 as 'the Norwegian Age', the period from around 1400 to 1520 as 'the English Age', the 16 ${ }^{\text {th }}$ century as 'the German Age' and identify the period from 1602 to 1787 as being the age of the Danish trade monopoly (Porsteinsson \& Jónsson 1991). Also, Jóhannesson (1965) divided the Medieval Period according to the importance of industries, i.e. the agricultural period (930-1300) and the fisheries period (1300-1500). These categorizations are known, and sometimes mentioned, but not commonly used (with the exception of the period of the Danish monopoly; for instance, see Nordal \& Kristinsson 1996).

More recently, historians have focussed less on the 'loss' of sovereignty and independence and the importance of the 'independence struggle' during the latter half of the $19^{\text {th }}$ century up until the creation of the Republic and more on other aspects 
Iceland's external affairs in the Middle Ages:

The shelter of Norwegian sea power

\section{Baldur pórhallsson}

\section{STJÓRNMÁL \\ STJÓRNSÝSLA}

of Icelandic life, such as the history of the family, crime and punishment, economic development and the origins of state power with regard to the relations between peasants and the aristocracy (see, for instance, Sigurðsson 2000; Dorláksson 2000; Júlíusson 2007). That said, the identification of the Cold War period as 'the American Period' in Iceland (Ingimundarson 2007) and 'the European Period', referring to a closer engagement with European integration by membership of the European Economic Area (1994) and Schengen (1995/2001) and the European Union membership application (Pórhallsson 2011), nevertheless involves reference to the location of power, formal and informal (i.e. in Washington DC and Brussels), rather than a reference to the importance of trade and alignment according to the international relations literature.

Small states and entities have always sought protection by their larger neighbours. This was the case of the ancient Greek city-states and European city-states (Pasquinucci 2002; Salvatori 2002). The economic growth of the city-states Venice, Lisbon, Genoa, Antwerp and Amsterdam was based on free trade and facilitated by small government. Their economic viability depended on their larger neighbours' willingness to undertake their defence, leaving them free to determine their own political actions in other respects. Also, free trade empowered small modern European states such as the Netherlands, Portugal, Denmark and Switzerland (Alesina \& Spolaore 2005, 176-184; see also Bairoch 1989) and while their 'non-alignment' may, at times, have kept them out of war, they were potentially at the mercy of larger states. This is especially the case of the smallest European states, San Marino, Monaco, Liechtenstein and Andorra. They have survived owing to their neighbours' willingness to respect their independence. These neighbours have largely incorporated the smallest states' economies and directly or indirectly guaranteed their defence (Oxford Analytica 2010). These historical accounts fit the most commonly used definition of what constitutes a small state, i.e. where smallness is seen in terms of measurable elements, such as number of inhabitants, geographical area, size of economy and military strength, and subjective elements, such as domestic and foreign actors' view of the state's size and capabilities (Archer and Nugent 2002).

Iceland in the Middle Ages, a society generally much more self-sufficient than in our times, may have experienced considerable autonomy (like many other small European entities), but it always sought economic and political engagement with its more powerful neighbours. The island, an outpost on Europe's northwestern edge, gradually followed its larger neighbours and became part of their formal boundaries. Centuries later, as nationalism swept through Europe, small entities gained importance, though it was not until the breakdown of the world order of the $19^{\text {th }}$ century in the first world war that several new countries were created in Europe (Alesina \& Spolaore 2005, 192), including Iceland. The de-colonization process in the post-war period and the collapse of the Soviet Union enhanced the creation of small states yet again.

In the late 1950s, international relations literature started to tackle this new world order characterized by small states (Baker Fox 1959). Generally, it claimed that small countries needed a protecting power, or needed to join an alliance, in order to be 


\section{STJÓRNSÝSLA}

economically and politically sustainable (Keohane 1969; Handel 1981; Archer \& Nugent 2002). The main reason was that they did not have resources to guarantee their own defences (Vital 1967). Besides, their small domestic markets, concentrated production (dependence often on only one export product) and greater reliance on exports and imports, and on exports to a single country or a particular market, made them more dependent on international trade than larger states. Hence, their economies would fluctuate more than larger economies and international economic crises would hit them with greater force than other states (Katzenstein 1984 \& 1985). These assumptions were based on the dependence of many small states on the two superpowers during the cold war and from observations of small countries and city-states in early times (for instance, see Alesina \& Spolaore 2005). The vulnerability of small states and their lack of capabilities (Neumann \& Gstöhl 2004) were further highlighted in the de-colonization process of the post-war period. Geographical location was seen as being of great importance, i.e. whether or not a small country was territorially based in a conflict zone and near a more powerful state. Also, the structure of the international system was of prime importance due to the better ability of small states to prosper during peacetime (Handel 1981) and in a world based on free trade (Katzenstein 1984 \& 1985) as compared with times of war and restricted international trade.

Lately, in the wake of the current international financial crisis and its devastating consequences for many 'prosperous' small states, the literature has been forced to turn back to its original findings on vulnerability (see, for instance, Schwartz 2011; Dórhallsson 2011) after a period in which many small European countries were described as successful and better capable than larger states of achieving economic growth (see, for instance, Katzenstein 1984 \& 1985; Briguglio, Cordina \& Kisanga 2006; Cooper \& Shaw 2009). Hence, the classic small-state literature, with its focus on the importance of a protecting power or alliance formation for small countries, has re-established itself as the core for understanding the status and role of small states in the international system.

This study places the case of Iceland in small-state theory within the framework of the international relations literature. The intention is to test an analysis of the need for shelter in the case of Iceland during the Middle Ages, from the Settlement around the turn of the $10^{\text {th }}$ century until the end of the $14^{\text {th }}$ century - a time of radical changes in the country's overseas relations. The paper is a part of 'a quintology': five papers which examine the concept of external shelter in the case of Iceland from the Settlement to the present day according to the importance of external relations. In addition to the present one on relations with the Norwegian crown, the others examine the importance of 'the English and German Periods'; the age of the Danish rule; the American Period; and the new European Period. The aim is not to re-write the history of Iceland. The purpose is rather to shed light on some aspects of the country's external affairs, such as trade and communications, which have been somewhat neglected in the historical narrative, and to start a debate on the importance of trade, peripheral location and foreign affairs in Iceland's history. External relations 
are examined by reviewing the extensive existing academic literature on the history of Iceland during this period.

The importance of economic and political shelter for small states, due to their more limited resources and means to withstand stress (Vital 1967) as compared to larger states, is related to three interrelated features: reduction of risk before an eventual crisis event; assistance in absorbing shocks when risk goes bad; and help in cleaning up after the event. There is a need to distinguish between economic and political shelter. Economic shelter may be in the form of direct economic assistance, a currency union, help from an external financial authority, beneficial loans, favourable market access, a common market, etc., provided by a more powerful country or by an international organization. Political shelter refers to direct and visible diplomatic or military backing in any given time of need by another state or an international organization, and through organizational rules and norms (Pórhallsson 2011).

Accordingly, with whom did Iceland have the closest economic ties during our period under study? Did they result in economic constraints or benefits which could be interpreted as economic shelter? With whom did Icelanders have the closest political ties? Did they result in political constraints or backing which could be interpreted as political shelter?

An understanding of the advantages of shelter addresses the present situation of small countries in the current international system. Therefore, an attempt to apply it to a small medieval entity/country needs to take into account the enormous difference in the nature of relations between states in this period as compared with modern times: we must bear in mind the non-existence of international organizations and the looser definitions of what constituted a state in the former period. Also, we must keep in mind that societies were generally much more self-sufficient in the Middle Ages than in our times. At the same time, for instance, it needs to address the role of 'an international actor', the Roman Catholic Church, and the implications of peripheral location during the Middle Ages.

There may be complications in applying a modern theory to the Medieval Period or any other past eras. On the other hand, realism, which exercised a hegemonic position in the study of international relations in the $20^{\text {th }}$ century, assumes that the nature of international relations has changed little, if at all, over the millennia. Realists trace their ideas about states'/entities' power struggle back at least as far as the ancient Greek city-states. Classical realism claims that states' behaviour is dictated by human nature, which is seen as destructive, selfish, competitive and aggressive. However, neorealism argues that the nature of interstate politics constructs states' behaviour. That said, they are unified in the assumption that their theories apply to the ancient world as well as the modern one (Sheehan 2005, 5-24). For instance, Alesina and Spolaore $(2005,178)$ argue that European city states (from about 1300 to about 1600) were, 'for the most part, politico-economic' entities that had some characteristics of today's open and democratic small states.

According to constructivists, (constructivism being a contemporary theory in the field of international relations), national discourse, international norms and practices 


\section{STJÓRNSÝSLA}

and notions of shared identity among states help us to understand domestic and external actions taken by a country's decision-makers. Additionally, Galasso (2012) argues that the individual socialisation and culture of decision-makers shapes a state's external relations, as was the case in the Roman Empire during the early Principate (from 27 B.C. to 284 A.D.). The norms and practices that constructed personal relations and relations between states, independent entities or semi-independent entities in the past were different from those which operate nowadays. On the other hand, studies, e.g. of the Greek city-state system and the Roman Empire, demonstrate that ancient key concepts like personal honour can be addressed in the modern international relations literature. For instance, constructivists often explore the linkages between culture, personal identity and state identity in order to explain foreign policy behaviour in historical world systems (see, Leira and Neumann 2007; Neumann 1994; Galasso 2012). Hence, cultural environments shape all historical world systems, i.e. cultural environments influence personal identity, and subsequently state identity, regardless of the period (Reus-Smit 1999).

Icelanders cannot be dealt with as a separate nation during our period under study, even though this was the time when the islanders' identity, and a notion that they differed from other Norse communities, started to take shape. Our findings will indicate that Iceland was a peripheral part of the Norwegian domain, though its autonomy, before and after submission to the crown, must not be underestimated. Also, it is problematic to refer to Iceland as a state, according to the Westphalian system (based on the concept of nation-state sovereignty, i.e. territoriality and the absence of external actors in domestic decision-making), during our period under review. However, the islanders made their first international agreement with the Norwegian king around the first quarter of the $11^{\text {th }}$ century and, at a similar time, 'noble' islanders started to represent the islanders as a group when meeting other noble men abroad. Moreover, the islanders enjoyed considerable autonomy after submission to the Norwegian crown.

Iceland started as an independent entity and then was voluntarily moved to a dependency relationship with Norway. One could say that submission to the crown was an extreme form of shelter while, at the same time, it was the only form of external shelter available. That all said, our concern is the extent of external engagement of the small community and its domestic consequences and whether the case fits the theory regarding the importance of external shelter for small societies.

Furthermore, a consideration of small states' exposure to threats has to take notice of the different levels and potential responses to threats in the Medieval Period compared to the situation in the present international system. This applies, for example, to violent crime, severe civil unrest, infrastructure, health challenges (including pandemics, natural disasters, environmental damage and food security), transport and the implications of Iceland's peripheral location, as already mentioned (see Bailes and Pórhallsson 2012 for present threats to small states). On the other hand, medieval small states were exposed to the traditional military and economic threats covered by the present international relations literature. 
Iceland's external affairs in the Middle Ages:

The shelter of Norwegian sea power

\section{Baldur pórhallsson}

\section{STJÓRNMÁL \\ STJÓRNSÝSLA}

The concept of shelter and the importance of alliances for small states may be linked to Rokkan and Urwin's (1983) historical account of the importance of centreperiphery relations in their attempts to explain state-building in Western Europe. The 'centre and periphery' model in the literature refers both to territories and inhabitants. Peripherality exists in three distinctive types of dominance of the centre(s), i.e. in politics, economy and culture. The authors argue that there are three key characteristics of peripheries: distance (location from the dominant centre), difference (at least some minimum level and sense of separate identity) and dependence (at least in terms of political decision-making, cultural standardization and economy). They prioritize the significance of distance, since it is important in the structuring of the peripheral economy and determines the ease or difficulty associated with the centre's attempt to control the periphery. Also, long distances make cultural communication more difficult and increase the likelihood of a separate identity. Furthermore, the authors identify three types of transactions which construct the centre-periphery relations in order to examine how dependent the periphery is upon the centre: economic (import/export of goods, services, labour, credits, investments, subsidies); cultural (transfer of messages, norms, lifestyles, ideologies, myths, ritual systems); and political (conflicts over territorial rights, wars, invasions, blockades, alliances and accommodations of different elites) (Rokkan \& Urwin 1983, 4).

Medieval Iceland was a peripheral community, in geographical terms: an outpost in northwestern Europe - only Greenland lay beyond it - according to the centreperipheral model. Also, the hegemonic medieval Roman Catholic and Icelandic world view was that Iceland was a marginal and peripheral entity far from the Christian centre (Jakobsson 2009). On the other hand, Karlsson $(2000,100)$ argues that Iceland lay at the centre of the Norwegian sea empire - not remote at all (though in terms of number of inhabitants it was on the periphery) - due to the closeness and short sailing time, in favourable wind, from Bergen, the king's residence, and Trondheim, the archbishop's seat. This was the case until the king's residence was moved to Oslo and a change of view took place within the Norwegian kingdom that it was a Nordic, and not a North Atlantic, monarchy, with possibilities of expansion to the south and south east, in the early $14^{\text {th }}$ century. Our concern has to do with how Iceland's external relations were structured: what economic, political and societal consequences did external affairs have for the islanders? Were they sheltered or not by their neighbours?

The paper argues that Iceland enjoyed important economic shelter from Norwegian sea power, particularly regarding its role in securing regular trade to and from the island throughout the period under study. Whether Iceland enjoyed political shelter from the Norwegian kingdom is more of a puzzle. The transfer of formal political power from Iceland to Norway can be regarded as a political cost. However, the key consideration is whether the traditional narrative of the history of Iceland has not neglected to examine whether the alignment with the kingdom, throughout the Middle Ages, provided political shelter for a considerable part of the domestic ruling elite. It, at least, benefited from the protection of the Norwegian crown, e.g. in terms of safer travel within its domains than might otherwise be anticipated. Also, internal problems 


\section{STJÓRNSÝSLA}

of order were to a certain extent halted, at least temporarily, as islanders submitted to the king. Accordingly, small-state literature needs to address how external actors may solve the problem of internal order. The submission entailed the creation of an executive branch of government - and, thus provided protection for the community at large. Confirming the importance of distance in the centre-peripheral relations model, Iceland's peripheral location shielded it from military attacks and constant interference by the crown. Furthermore, an analysis of the need for shelter needs to address a small state's potential political and economic cost associated with alignment with a larger country.

Importantly, Iceland - despite its geographical remoteness - was not at all unexposed to political and social developments in Norway and in the British Isles and on the European continent, e.g. as regards the conversion to Christianity and the creation of a dynastic state. This paper claims that the case of Iceland indicates that the assumption that a small state needs economic and political protection must also address the importance of the extent of engagement of a small community, particularly a remote one, with the outside world. The level of engagement and the entity or entities with which relations take place may have an important bearing on the community at large. Hence, the paper suggests that an analysis of the need for shelter should examine the importance of cultural or social communication according to Rokkan and Urwin's (1983) centre-periphery relations model. The traditional Icelandic historical narrative has neglected the importance of the Norwegian economic and societal shelter and side-lined the protection which at least some chieftains and other rich farmers gained by closer engagement with Norwegian sea power and international developments in Europe concerning dynastic state building during the era.

The paper is divided into three sections in addition to this introduction and a concluding chapter. First, it starts by examining Iceland's external trade relations and considering whether or not Iceland enjoyed economic protection during the Middle Ages. Second, the entity's/country's political engagement with Norway and other international actors is examined in order to identify the political aspect of the shelter concept. Third, the importance of external social communication, i.e. societal shelter, is put under scrutiny. The concluding part summarizes the main findings and proposes suggestions to enhance our understanding of the advantages of shelter.

\section{The Norwegian market link: Economic shelter?}

Scholars disagree somewhat about the content and extent of Iceland's external trade, the number of ships sailing to and from the country and the final destination of exports during the Middle Ages. Nevertheless, there is a unanimous consensus among them that Norwegian sea power provided Iceland with an external link with the outside world.

During the early Middle Ages, a form of common market existed in northwestern Europe (see Figure 1), though farmers' communities had largely to be self-sufficient due to transport difficulties. The Norsemen were one of the most prominent maritime peoples during the Viking Age (from around 800 to the mid- $11^{\text {th }}$ century) ${ }^{1}$ and 


\section{Baldur pórhallsson}

established settlements in the British Isles (in England, Scotland, Ireland, Shetland and the Orkneys) and the Faroe Islands before reaching Iceland. Wealthy farmers and community leaders in these various outposts, and in Denmark and southern Sweden, were connected with each other by marriage, educational and cultural exchanges and trading (Líndal 1974).

Figure 1. Iceland's economic shelter: The common Norse market area acknowledging Norwegian sea power from the $9^{\text {th }}$ to the $14^{\text {th }}$ century.

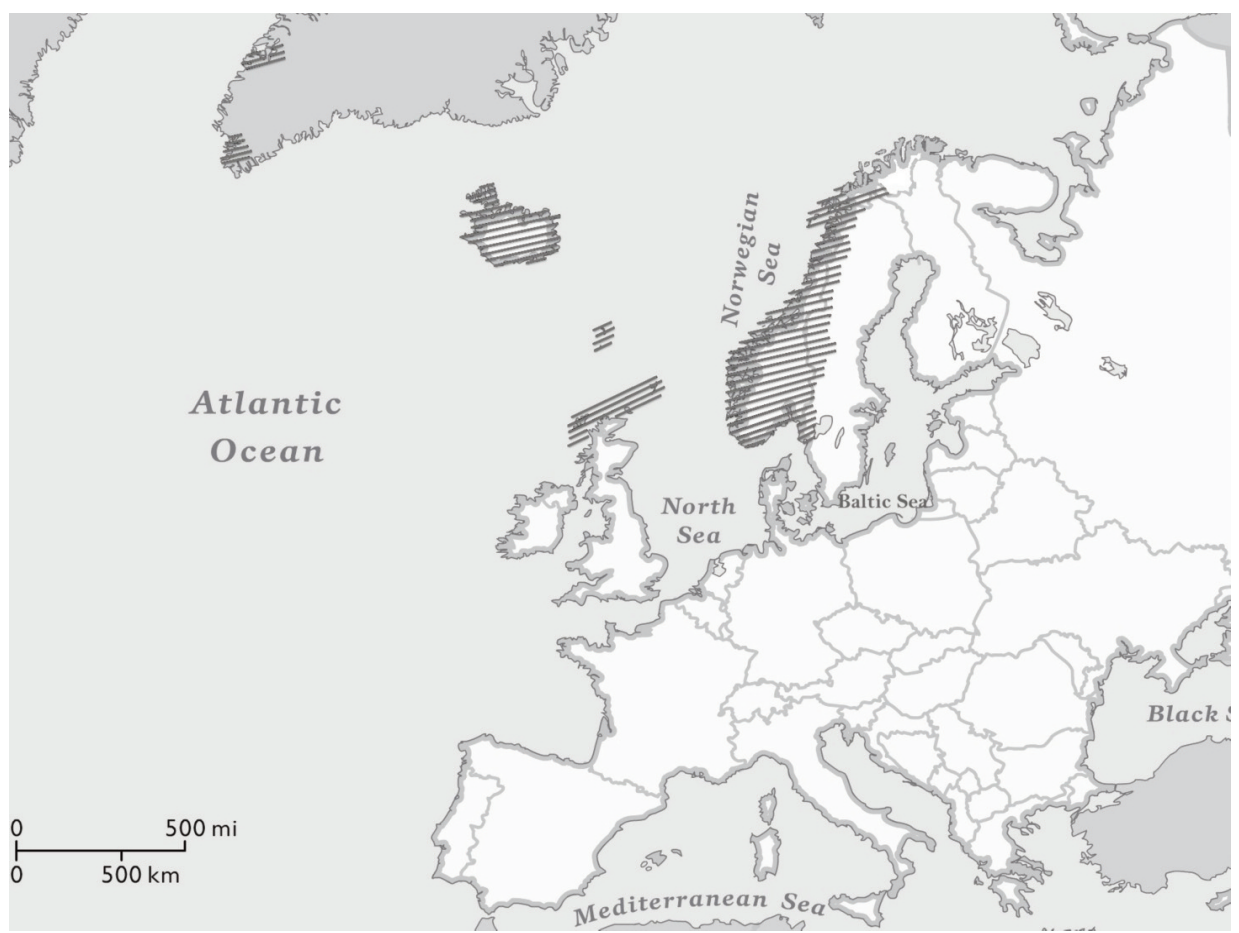

Sources: Based on numerous accounts of trade, such as those in Porsteinsson \& Líndal 1978, 39 and Karlsson 2000, 104.

A shipping fleet capable of sailing long distances in rough waters was essential for all communication and trading with the outside world. Until the $11^{\text {th }}$ century, the settlers in Iceland seem to have owned a considerable number of ships with the capacity to sail to other parts of northwestern Europe, though there are few historical records about foreign trade during the Commonwealth - especially its first half. During this period, Icelanders seem to have been in control of their own trade with the rest of the Norse world and records indicate that 35 ships came to Iceland in 1118 (Karlsson 1975). Formally, regional chieftains, in the Althing, regulated foreign trade, though it appears to have been relatively free, at least during the first decades of the Commonwealth 


\section{STJÓRNSÝSLA}

(Jóhannesson 1974). During the Commonwealth era, chieftains may have tried to control the prices of imports, but with limited effect (Karlsson 1975, 20-21)

In the $12^{\text {th }}$ century, Icelanders were still in control of some of their external trade. However, they were not in charge of the shipping fleet sailing to and from the country. At the turn of the $13^{\text {th }}$ century, most trade was in the hands of foreigners primarily Norwegians but also their distant relatives in the British Isles (mainly the Orkneys) - and few ships, if any, seem to have been owned solely by Icelanders (Líndal 1974). Little wood, inefficient tools, limited skills and several problems relating to the use of driftwood contributed to this situation. Nor is it likely that the profits from trade would cover the costs and huge risks involved for individual farmers in sailing in the turbulent waters around the island (Kristjánsson 1975, 199-201). Nevertheless, Iceland's two episcopal sees, some rich farmers and some of the king's administrative officials on the island owned shares in some ships, i.e. those who took part in the trade to and from the island, including the bishops and the archbishop in Trondheim, diversified their risk by sharing ownership of both ships and cargo (Porsteinsson \& Grímsdóttir 1989, 179-180).

In the first centuries after the Settlement, sailors would land their ships at various places along the coastline but in the $13^{\text {th }}$ century records mention only ten harbours. This may be related to fewer ships and sailings from and to the island and the fact that Norse merchants would attempt to land at 'good' and known 'natural' harbours close to populated areas. Fairs were set up by the harbours for the convenience of farmers and traders. Trading mainly took the form of barter. Icelanders who travelled abroad had to carry goods with them as payment for their daily expenditure and to pay the landing tax in Norway, as will be discussed below. Some records indicate a sense of solidarity between the people of the two entities: for instance, in 1056, during a time of great hardship, the king sent four ships to Iceland carrying grain that was supposed to be sold at a reasonable price, and allowed poor Icelanders to travel abroad (Líndal 1974).

In Norway, villages where merchants and associates of the archbishop and the king took over the trade started to emerge in the $11^{\text {th }}$ century. These provided better facilities for commerce and increased revenues. Bergen, on the west coast of Norway, became the main commercial centre of the Nordic countries (Líndal 1974). For instance, Norwegian merchants became Nordic Greenlanders' link with the outside world (Kjartansson 1996, 64), with contact throughout the Norse world.

Part-time trading activities by the rich Icelandic farmers could not compete with this 'newly rich' trading class in Norway. The small Icelandic domestic market, its almost total reliance on a single export product, vadmál (homespun woollen cloth), transport difficulties and the high costs associated with the country's peripheral location contributed to the fact that commerce did not become a profession and no villages were created. Moreover, the reserves of silver brought by the settler population are thought to have been exhausted in the $11^{\text {th }}$ century. Icelandic farmers also exported skin, sulphur and falcons (Karlsson 2009) and, in the early $13^{\text {th }}$ century, Icelanders demanded that the Norwegian king ban the export of grain in times of domestic 
Iceland's external affairs in the Middle Ages:

The shelter of Norwegian sea power

\section{Baldur pórhallsson}

\section{STJÓRNMÁL \\ STJÓRNSÝSLA}

need (Porsteinsson \& Jónsson 1991). The main imports consisted of grain, in addition to timber, tar, canvas and wax and other goods. Grain and timber were of the greatest importance: domestic production could never satisfy internal demand and timber was essential for building fishing boats (and was thus probably the most important import) and houses (Karlsson 1975). Also, it has been argued that Iceland was an important transshipment centre for shipments of valuable goods such as ivory (walrus teeth) and skins from Greenland to Western Europe (Guðmundsson 2002, 42-80) while other scholars claim that there is limited evidence for Iceland as a transshipment centre (Vésteinsson 2005).

The importance of trade relations for Iceland is manifested in the much-quoted provision in the agreement between Iceland and the Norwegian king in 1262, later termed the Old Covenant ${ }^{2}$, stating that the king guaranteed that six ships would sail from Norway to Iceland in the following two summers and, thereafter, as many ships would sail to Iceland as the king and leading Icelandic farmers thought appropriate. This meant that there were twelve ships sailing between the two countries, six from Iceland in the summer and six to Iceland, where they remained throughout the winter (since sailing to Iceland was only possible during the summer). It must be remembered that ships often failed to reach their destination due to difficult sailing conditions. For instance, records indicate that in the period 1262 to 1412, ships failed to reach Iceland entirely in five years, and in six years only one ship arrived in Iceland (Porsteinsson \& Grímsdóttir 1989, 168). The sailing clause in the Old Covenant was restated in 1302 and, again, nearly twenty years later, in a letter to the king, a request was made for two ships to be sent to the south of Iceland, two to the north, one to the West Fjords and one to the east coast (Porsteinsson \& Grímsdóttir 1989). Hence, inadequate transport affected the extent of exports and imports. One wonders whether the rich farmers and the bishops had only their own needs in mind when deciding on the number of ships to and from the island (Porsteinsson 1964; Karlsson 1975, 19) and/or whether their priority was to secure communications and meet the needs of their colleagues abroad - as will be discussed below. Certainly, six ships could carry considerable amounts of Iceland's main medieval exports, vadmál and stockfish (gutted and winddried fish) (Dorláksson 1991). Several other historians have also made an attempt to calculate the amount of goods that ships sailing to and from the island could carry. For instance, Karlsson (2009, 237-39) argues that six ships could carry the island's entire vadmál production (not for domestic use) and that they could carry about 100 to 140 kilos of imported goods for every single household in the country. Findings vary considerably but indicate that six ships might have been able to carry a considerable amount of stock that was, at least, 'enough' for the domestic consumption by rich farmers and bishops and even by the population at large (if the ships reached shore; for a good overview, see Karlsson 2009 and Porláksson 1991).

Iceland's exports underwent changes reflecting developments in trade and fashion in the rest of Europe. Clothes made with felted woollen cloth were an important export in the $11^{\text {th }}$ and $12^{\text {th }}$ centuries but around 1200 they dropped out completely, probably due to changes in fashion. In the $13^{\text {th }}$ century, exports of skin were in 


\section{STJÓRNSÝSLA}

decline due to the import of less costly skins from the East by the Hansa merchants (Karlsson 1975). During the early period, Iceland's exports reached England and Germany, though there is no mention of sailings by English and German merchants to Iceland. In the $13^{\text {th }}$ century, profits from trade seem to have been in decline, which led to an economic downturn. This changed with a new main export commodity and a 'new' and larger market and a better access to it (Dorsteinsson \& Grímsdóttir 1989).

In the early $14^{\text {th }}$ century, Iceland's exports underwent fundamental changes following a radical shift in trade in Western Europe. Stockfish and oil gradually took over from vadmál as Iceland's main exports (Porláksson 1991). Marine products became the country's main exports and have remained so ever since (Kristjánsson 1980; Jóhannesson 1965). Iceland became a full participant in fishing and maritime trading in the North Atlantic (Dór 2002). Vadmál exports had been in decline for some time: textiles from Flanders, England and elsewhere had taken over the European market (Porsteinsson \& Grímsdóttir 1989).

The traditional explanation refers to the relative decline in the importance of the Norwegian sea empire coinciding with population increases in Europe and the emergence of important cities on the Baltic Sea from Lübeck to Tallinn. Hansa merchants became prominent in the increased trade between the industrial regions, at the time, of Western Europe and the 'new' cities from the late $13^{\text {th }}$ and early $14^{\text {th }}$ century. They took the lead in the Baltic Sea trade. In the mid- $14^{\text {th }}$ century, the Hanseatic League was in control of most of the trade in Northern, northeastern and Western Europe, particularly in trade with fish and grain (Stabel 2001).

Accordingly, the centre of trade shifted from the northwest to the Baltic Sea and Western Europe. The new Christian cities now under German control needed fish for the Christian fasts and oil (fish liver oil) to light up their dark streets. Already in the $12^{\text {th }}$ century, German merchants did considerable trade with northern Norway in exchange for grain. Grain production declined significantly in Norway and its domestic yield was not sufficient to feed the increasing population. In 1343, Bergen became the location of one of the four main Hanseatic offices (Kontore), the others being in Bruges, London and Novgorod. By 1400, approximately 3,000 of the town's population of 14,000 were Germans (Gade 1951). Norway now depended on trade with the Hansa merchants and they received more favourable trade terms than merchants from other countries, particularly England. The Norwegian fishing industry and exports flourished and the centre of trade shifted from the settlements of the Northwest Atlantic, where little or no grain could be produced, eastwards to the Baltic Sea. Norwegian engagement with England declined significantly (Nielssen 2001, 185-190).

Gradually, the Hansa merchants took charge of most of the Norwegian trade, thanks to their superior coordination and greater financial resources and also their larger ships, which were essential for the massive volume of trade between Norway and the Hanseatic cities. However, they were not in full control. Norwegian merchants kept their status as the only ones to engage in regular trade with the islands to their west, including Iceland, up until the end of the $14^{\text {th }}$ century (see Figures 1 and 2) (Porsteinsson 1964). The Norwegian link kept Iceland within the boundaries of the 
Iceland's external affairs in the Middle Ages:

\section{Baldur pórhallsson}

well-integrated and functioning economic area of the North Sea and the Baltic regions, as Figure 2 indicates (Brand \& Müller 2007).

Figure 2. Iceland's economic shelter: Market access provided by Norway to the Hanseatic League and England in the $13^{\text {th }}$ and $14^{\text {th }}$ century.

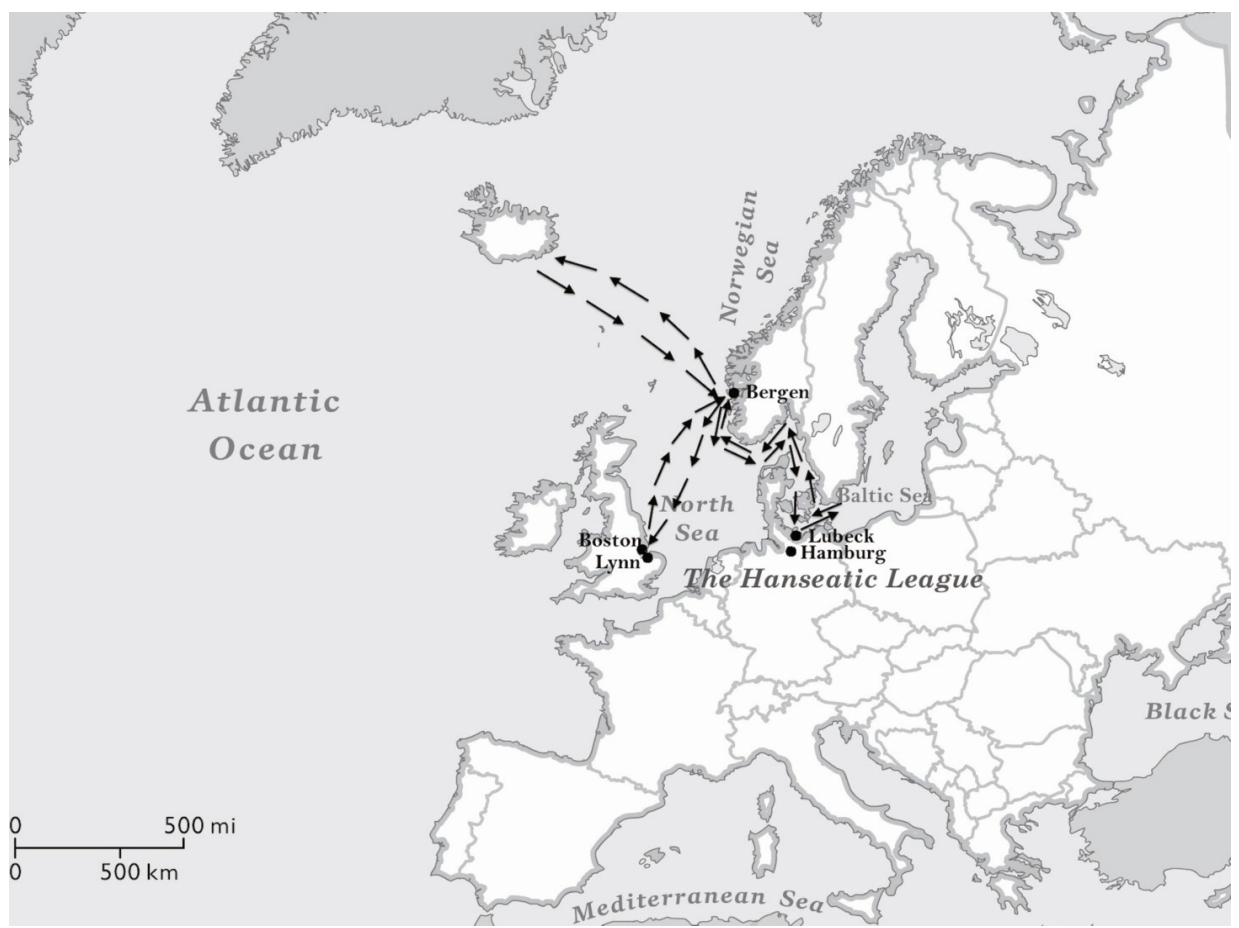

Sources: Based on numerous accounts of trade, such as those in Porláksson 1991 and Porsteinsson \& Grímsdóttir 1989.

Importantly, Norwegian merchants in Bergen controlled trade with Iceland and provided access for Icelandic exports to the Hanseatic and English markets (see Figure 2). The common explanation is that Iceland exported stockfish and oil to the Hanseatic League in exchange for grain. Stockfish had been exported from the country for a considerable time but now reached new heights with new market access and higher prices. This led partly to a change in employment, at least seasonally, and may have stimulated residence on the coast in the west and south of the country. New harbours were, at last, closer to rich fishing grounds (Dorsteinsson \& Grímsdóttir 1989, 174). Foreign trade seems to have been particularly lively in the fifth decade of the $14^{\text {th }}$ century, as more ships than before came to Iceland. High prices for stockfish probably contributed to the boom (Dorsteinsson \& Jónsson 1991, 135-137). Those farmers who profited most from stockfish exports became richer than anyone had been before in the country. The general public probably experienced economic deprivation (due to colder weather conditions, reduction 


\section{STJÓRNSÝSLA}

in the amount of cultivated land and increased taxation by big landowners, i.e. the rich farmers, the church and the crown) in the $13^{\text {th }}$ and $14^{\text {th }}$ century (Karlsson 1989, 203-205).

This growth most likely came to a halt in an epidemic, the Black Death (1349-50), which had devastating effects in Norway and elsewhere in Europe - though it did not reach Iceland since ships failed to leave for the island during the plague. One third to half of the Norwegian population is estimated to have died. Bergen's merchants had difficulties in maintaining their former level of trade after the epidemic and, additionally, Norway's war with its Scandinavian neighbours affected its capacity to maintain its former level of trade with its tributaries. Shipping to Iceland went back to a level of activity similar to what it had been before 1340. The Norwegian king increased taxation in Iceland due to a steep fall in tax revenues from other parts of the kingdom. Exported goods from Iceland were now subject to a five per cent tariff and the six ships in regular sailings to and from the island had to provide the crown with a quarter of their space for goods. Moreover, the king started to rent out the tax province, Iceland, with taxation and obligations for three continuous years for a specific price. Most of the 'rent seneschals' were Icelandic but Bergen became Iceland's formal commercial and administrative centre in order to guarantee tax collection. Nevertheless, the Norwegian kingdom experienced regular tax collection difficulties due to tax revolts and interruptions in sailings from the country (Porsteinsson \& Jónsson 1991, 141-142).

Bergen provided Iceland with access to the outside world and its merchants had the king's backing in their attempt to create a centre for Norwegian trade and administrative functions, as Figure 2 demonstrates. In the period from 1284 to 1348, there were no restrictions on sailing by subjects of the Norwegian crown to Iceland (Porsteinsson 1964). On the other hand, in the last decade of the $13^{\text {th }}$ century, Germans had been forbidden to sail north of Bergen; early in the $14^{\text {th }}$ century, this rule was extended to all foreigners and covered Iceland and other tax provinces of the Norwegian crown (Porsteinsson \& Jónsson 1991). In 1348, all seamen were forbidden to sail to Norwegian dependencies without special permission from the Norwegian king (Porsteinsson 1964). Bergen was now the centre of trade with the Hansa towns: all stockfish from the Norwegian kingdom had to be exported through the city. Accordingly, Bergen's merchants had a monopoly on trade with Iceland until the last decade of the $14^{\text {th }}$ century. Records indicate that Icelanders made three attempts to build ships and sail to Norway but all the ships were confiscated due to the monopoly. Nearly all, if not all, communications between Iceland and the outside world were via Bergen (Porsteinsson \& Jónsson 1991).

porláksson (1991 \& 2001) agrees that Norwegian merchants were the only ones to provide Iceland with access to foreign markets (see Figures 1 and 2) but disputes the importance of stockfish and its export to the Hansa regions in the $14^{\text {th }}$ century. First, he claims that vadmál was still an important source of Icelandic export earnings and that as late as about 1390, Icelanders were fulfilling considerable demand for highquality Icelandic vadmál in Norway. Nor should exports of oil, sulphur and falcons be forgotten. Moreover, he argues that domestic population increases and changes in food consumption, and not external demands for stockfish, were the main reasons 
Iceland's external affairs in the Middle Ages:

The shelter of Norwegian sea power

\section{Baldur pórhallsson}

\section{STJÓRNMÁL \\ STJÓRNSÝSLA}

for fishing becoming important in the second half of the $13^{\text {th }}$ century (Dorláksson 2003 and 2001). In fact, he claims that the stockfish export boom did not start until about 1330 and later, and came to a halt with the Black Death, and that it was not extensive in the late $14^{\text {th }}$ century.

Second, Porláksson (2001) argues that most of the stockfish from Iceland went, through Bergen, to England. At the beginning of the $14^{\text {th }}$ century, the BergenEngland trade, including Icelandic stockfish at least from 1307, was conducted by Norwegians but later by both Hansa and English merchants, mainly the latter. $\mathrm{He}$ argues that there was considerable demand for Icelandic stockfish in England, and none at all in the Hansa region on the Continent due to a different process of handling of Icelandic stockfish, which was disliked on the Continent, compared to stockfish from Norway, and also due to irregular sailings to Iceland. He claims that the increased (though irregular) numbers of Norwegian ships reaching Iceland from 1375 to 1392 is related to stockfish demand. Norwegian sailings to Iceland declined significantly after the failure of ten ships from Bergen to reach Iceland in 1392.

Fishing in Iceland continued to be the secondary activity of some farmers and their servants and was pursued mainly during the winter season only, despite the importance of stockfish and the fact that Iceland did not share its waters with others. Norway had rich fishing grounds of its own and other countries' ships did not have the capacity yet to sail as far as Iceland (Porsteinsson \& Grímsdóttir 1990, 15). Fishermen used primitive open rowboats which could go only a few miles and return to land the same day (Gunnarsson 1980). Fishing was mainly inshore and in coastal waters; the richest identifiable fishing grounds were located off the southwestern coast of the island (Thoroddsen 1924). The population continued to be widely spread over the habitable part of the country. The largest inhabited places, the two bishops' seats, were far from the coast and thus did not develop into commercial centres. The fact that manors were spread out in the country and domestic travel was very difficult also did not help the small volume of internal trade to develop (Porsteinsson \& Jónsson 1991, 137).

Eggertsson (1996) argues that Iceland failed to develop a strong specialized fishing industry and relates this to the peripheral status of the island in the late Middle Ages within the Norwegian kingdom and, later, the Danish kingdom. Also, he links this to the challenge from the crown to cooperation between Icelanders and outsiders (i.e. the failure to adopt free trade) - and some important distinctive domestic features: the king's unwillingness to invest substantial resources 'in isolated and distant Iceland' may suggest that 'the transaction costs of developing a strong presence there were thought to outweigh the benefits' (Eggertsson 1996, 6) and that the island was of marginal interest to the crown. Eggertsson's external explanations may be accurate: the Norwegian crown's failure to invest in the country's rich fishing grounds and the trade and sailing restrictions and taxation imposed constraints on the development of a strong industriallybased fisheries sector. However, he is in danger of overlooking conditions on the economically stagnant island in the $12^{\text {th }}$ century - a remote island which no longer had its own shipping fleet and depended on the outside world for timber, fishing gear and 


\section{STJÓRNSÝSLA}

technology. Its silver reserves were gone and it could only trade by barter. Moreover, European dynasties did not regard it as their role to invest in industries and leading domestic farmers gave priority to agricultural production at the expense of the fishing industry during the period under review. Norwegian merchants, with the king's support, undertook the task (for their own benefit of course), of providing market access for the country's exports. Eggertsson touches on a critical feature of this small peripheral community when stating that the small scale of economic activity in Iceland demanded critical external inputs and international marketing services. These were not available, but the Norwegian merchants and the king nevertheless provided a link to the outside world, i.e. input in the form of a shipping fleet for transport and market services for the Norse market and, later, the important German and English markets. Iceland's engagement with the Norwegian kingdom provided foreign contacts and access to export markets and transformed the country's economy from being almost totally based on farming to being partly based on fishing. Marine products became the country's main exports and have remained so ever since - as has already been stated.

To conclude, the Norwegian kingdom taxed Icelandic products when they reached Norwegian soil and, later, inland and, at times, placed various restrictions on trade with Icelanders. It did not build a decisive industrial base and commercial villages or centres in Iceland (as it did in Norway) or develop the country's domestic infrastructure. That all said, an important part of this economic-relations picture between the two entities is missing: the Norwegian link provided essential economic shelter through transportation and trade.

\section{Norse influence in Iceland: Political shelter?}

Formal relations with foreign authorities cannot be identified until the $11^{\text {th }}$ century. They were mainly with the Norwegian crown and the church. For instance, Icelandic bishops, and those who were about to be consecrated as bishops, would represent their island/country and receive guidelines for their followers. This was the case of the first Icelandic bishop who went to see the Pope and the Roman-German Emperor (Líndal 1974, 258). On the other hand, Porsteinsson (1966, 148-49) argues that Icelanders were in direct political relations with the Norwegian king even from the time of the Settlement, evidence for this being the settlers' requests to him to solve disputes regarding the Settlement.

Already in the $11^{\text {th }}$ century, the Icelanders seem to have identified themselves as Icelanders though this was most likely as a term of reference to people from the country rather than as a nation (Jakobsson 2005). A clear distinction seems to have been drawn between those who lived on the island and those from abroad, though the legal status of Icelanders and foreigners was much the same during the Commonwealth era (Líndal 1974).

Iceland's first international agreement was made with the Norwegian king in 1022 and was updated twice, the second time in 1083. This agreement listed the rights of the king and his Norwegian associates in Iceland and the rights of Icelanders in 
Iceland's external affairs in the Middle Ages:

The shelter of Norwegian sea power

\section{Baldur pórhallsson}

STJÓRNMÁL

STJÓRNSÝSLA

Norway. Icelanders had two obligations under the agreement. First, those who travelled to Norway had to pay tax when they reached shore (some were exempted from it, including all those who were driven off course from Iceland to Norway). This tax was quite high, but varied from one period to another. Second, Icelanders in Norway had to be prepared to serve in the defence of Norway and the crown in the event of an invasion. Many Icelanders are recorded as having fought alongside the king (Líndal 1974, 221-222). On the other hand, Icelanders were assured safe travel within the Norwegian kingdom; this was not the case when they travelled to Ireland, Scotland, Denmark and France, where Icelandic ships are mentioned as having been confiscated, as Figure 3 indicates (Dorsteinsson 1964, 49; Karlsson 2009, 243).

Figure 3. Iceland's political shelter provided by Norway from the $11^{\text {th }}$ to the $14^{\text {th }}$ century.

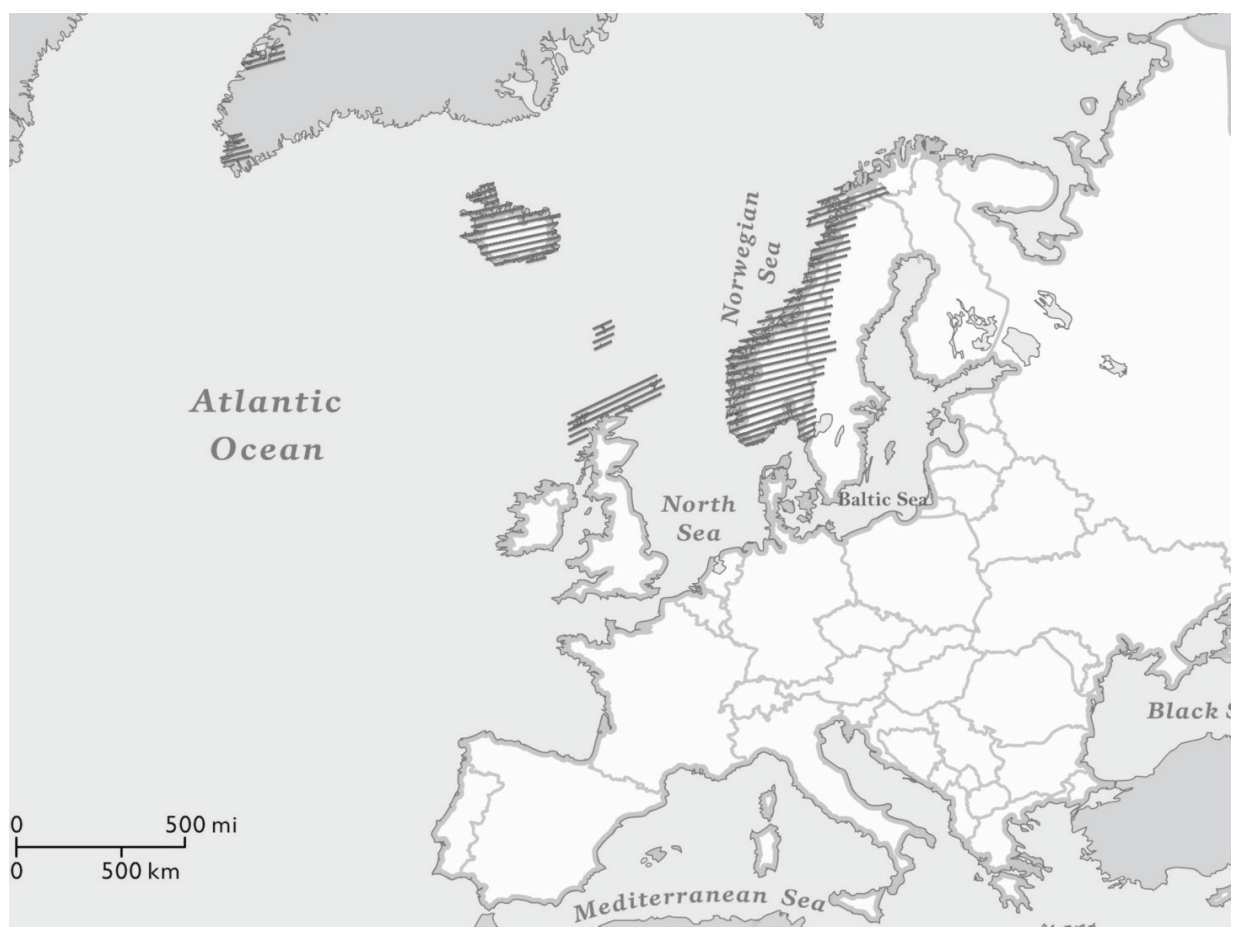

Sources: Based on numerous accounts of the area under the control of the Norwegian king, such as those in Porsteinsson \& Líndal 1978, 39 and Karlsson 2000, 104.

Dorsteinsson and Jónsson (1991, 50-59) mention that the agreement may be interpreted as 'a security union with Norway' without taking that assumption much further. The agreement indicates that Icelanders travelled somewhat during this period and passed through Norway on their way to the rest of Europe. They had to rely on Norwegian rules in their relations with the outside world and paid high taxes for the 


\section{STJÓRNSÝSLA}

king's protection within his jurisdiction and, thus, accepted the agreement's obligations (see also Porsteinsson 1964). Dorsteinsson (1966) argues that in the early $11^{\text {th }}$ century, countries' boundaries in Northern Europe and by the North Sea became clearer. Accordingly, Icelanders had to make an agreement with a king in order to travel peacefully: the only option was to make an arrangement with the Norwegian king (see Figure 3). Icelanders most often had representatives at the Norwegian court, and Icelandic poets were even amongst the king's advisers.

The remoteness of the island protected it from outside military attacks since military ships of the era were not capable of reaching it. Also, the island did not have any such valuable domestic resources that would make a hostile takeover worthwhile. Hence, Icelanders did not have to organize defences like most other countries in Europe had to. This probably had considerable effect on the governance of the country, which lacked an executive branch of government during the Commonwealth period (Kristjánsson 1975, 219-220). Moreover, the distance from Norway made it difficult for the king to exercise his influence on the island, though he made several successful attempts and was already very influential within the country before the submission to the crown (Karlsson 1975). For instance, towards the end of the $13^{\text {th }}$ century, when the king called on Icelanders on the island to fight on his side in Norway, within their own kingdom, they resisted and got away with it - only few are thought to have accepted the military call (Porsteinsson \& Líndal 1978). That said, Norwegian kings are thought to have regarded it their sole right to govern Norse settlements. Several records demonstrate their intention to take control of Iceland. For instance, the intense pressure by the Norwegian king to convert Iceland to Christianity is regarded as part of the crown's attempt to govern the country and the rest of the Norse world (Kristjánsson 1975, 219-220).

The attempt to guarantee regular shipping to Iceland was not only to do with the importance of trade: it was essential for all communication with the outside world. The king's influence and tax collection in the country were secured by regular contacts with the local ruling elite, the clergy kept informed about the Roman Catholic Church's line by travelling and other exchanges of information and Icelanders took part in pilgrimages and crusades. ${ }^{3}$ Regular communications kept Iceland on the European map and ensured the continuation of Norwegian and other European influence on the small community (see Figures 1 and 2).

The creation of a separate archbishopric in Trondheim in Norway in the mid- $12^{\text {th }}$ century - after it had been fully or partly located in Lund within the Danish kingdom at the turn of the century - ensured the continuation of Norwegian influence in Iceland. Moreover, Icelandic domestic affairs fell into line with the developments on the Continent, i.e. greater independence of the Roman Church from the secular power and more demands of its servants and followers for, and establishment of, monasteries and nunneries (Kjartansson 1996, 67).

According to Jakobsson (2005), the decision to bring Iceland under the Norwegian kingdom may have had a considerable effect on Icelanders' tendency to identify themselves as a specific group distinct from others in the Nordic region. He argues 
Iceland's external affairs in the Middle Ages:

The shelter of Norwegian sea power

\section{Baldur pórhallsson}

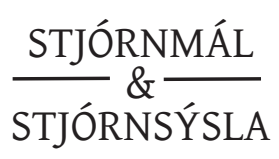

that it is problematic to speak of a specific Icelandic world view in the Middle Ages (1100-1400). Icelanders had adapted to the Roman Catholic world view, which emphasized the unity of all Christians. Also, Icelandic farmers' outlook centred chiefly on their own community and personal connections mattered more than loyalty to a specific geographical governmental authority (Jakobsson 2005, 366; Júlíusson 2007, 6). That said, prestige within the Norwegian royal court was important for the Icelandic identity: '...the identity was realized there rather than back in Iceland. Tales of solidarity among Icelanders take place especially in Norway or in dealing with the Norwegian king. And it was not until Iceland became a part of the Norwegian kingdom that the Icelandic identity became assertive at home in connection with all sorts of opposition to changes and innovations by the foreign government' (Jakobsson 2005, 366). This was partly a break with the past since the Norse world, including Iceland, drew its identity from ideas about a common origin of Scandinavians in Asia. This common origin united Scandinavians with the others outside the region. The Norse communities saw themselves as forming the northern part of Christendom (with its centre in the Mediterranean) - i.e. their importance was subsidiary to being part of a greater entity (Jakobsson 2005, 365).

Porsteinsson and Jónsson (1991) argue that according to its wording, the Old Covenant was a unilateral declaration by farmers (land owners) - not chieftains made with the aim of solving serious disturbances in transport logistics and remedying the lack of an executive branch of government of the Commonwealth period and establishing peace after a period of civil war. They acknowledged the Norwegian king and agreed to pay taxes to the crown but otherwise held on to their powers and prestige. Hence, the crown would establish peace, guarantee regular sailings and Icelanders would have a say in the making of their own laws (rules). In 1302, the Old Covenant was updated and new clauses were added to it (Porsteinsson \& Jónsson 1991, 119-130). Jakobsson (2007) supports the view that peace was the farmers' main aim in accepting the authority of the crown. Moreover, Hálfdanarson (2001b) describes the Old Covenant as a Social Contract, according to Locke's definition, providing for the creation of an executive branch of government in Iceland. Together, the establishment of the Althing, which was a domestic decision to create a society (providing for a judiciary and unified internal law), and the Old Covenant, which was an agreement with the Norwegian king (on executive power), form the Icelandic Social Contract.

New 'laws' (rules) were now 'given' by the king. They were subject to consent by the Althing, which could initiate legislation by petitioning the king and pass its own resolutions supplementing royal law (rules). The main function of the Althing continued to be, as before, judicial. Iceland depended on trade with Norway and local leaders were eager to accept royal patronage. They managed 'to fend off royal demands for military or financial contributions above the moderate regular tax' (Kjartansson 1996, 70) and were particularly successful in keeping royal and ecclesiastical appointments to themselves. The peripheral location of the country within the kingdom allowed for a certain level of manipulation of the crown's power by the domestic elite (Júlíusson 2007, 6). Júlíusson (2007) argues that 'the local aristo- 


\section{STJÓRNSÝSLA}

cracy developed strong feudalizing tendencies in fact, if not formally' and that these tendencies can be traced back to the period between Settlement and the $11^{\text {th }}$ century. Hence, Icelanders continued to exercise considerable autonomy, though 'the Norwegian king acquired property rights to all trade with Iceland, including the right to determine (at least formally) what foreign merchants could enter the trade' (Gunnarsson 1987, 74). In 1383 these rights were passed to the Danish kingdom as it took Iceland over from Norway. In fact, from 1319, Norwegian kings had become less engaged in Icelandic affairs than before. They were often based outside Norway, mainly in Sweden, and had more important issues on their agenda than this distant fief. For instance, trade with Iceland was affected by the ongoing clashes between and within the Nordic kingdoms in 1365-70. The Norwegian king may often have considered himself lucky if he received tax revenues from Iceland (Dorláksson 2003, 243). In 1380, the Norwegian and the Danish kingdoms were to merge, which later led to the creation of the Kalmar Union (1397), including Sweden. The Danes gradually assumed the leading role in this union.

Iceland was regarded as a peripheral Norwegian entity, and, as such, was not part of any arrangements regarding the Kalmar Union or the earlier changes in royal authority in Scandinavia. Icelanders seem never to have had any concerns about the formal legal status of the country in relation to the three Nordic countries or any other countries (Porsteinsson \& Grímsdóttir 1989, 246). Leading Icelandic farmers would sometimes write 'bills of rights' in connection with oaths of allegiance to a new king in the country (documents such as the Old Covenant in 1262-64 and 1302 and the Skálholt Agreement of 1375). These indicate that rich farmers were concerned with retaining their own freedom and previously arranged privileges. For instance, they demanded to have the right to approve all new taxation and official appointments by the king in the country. The same applied to their rights to have a say in law-making and judiciary procedures. They were not concerned with aspects of Icelandic-Norwegian relations such as kings' elections (they always swore allegiance to the elected king who promised to respect their traditional rights) and the general status of Iceland within the kingdom. For instance, they seem either not to have interfered in changes to the governance of Norway or simply to have approved them (Porsteinsson \& Grímsdóttir 1989, 246-247).

In the Middle Ages, the relationship between Norway and Iceland was characterized by a typical dependence of the smaller entity, i.e. the peripheral island depended on the larger and more centrally located entity, Norway, which accords with the model in small-state literature. Moreover, relations between the two entities bear the clear hallmark of the development of interactions between other entities (regions and states) in Europe: 'the Europe that was emerging generally favoured the institution of monarchical states as well as conversion to Christianity. Europe was represented by a collection of kings' (Le Goff 2005, 45). In other words, the relationship followed the development of the international system at the time.

In the first centuries, Iceland was formally politically separate but under strong formal and informal influence from the Norwegian kingdom regarding its decisionmaking; examples are the conversion to Christianity and the agreements on the rights of the king and his officials in Iceland and the rights and duties of Icelanders in 
Iceland's external affairs in the Middle Ages:

The shelter of Norwegian sea power

Baldur Pórhallsson

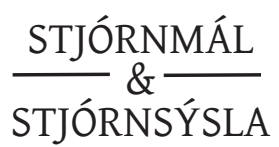

Norway, e.g. as regarding tax and military service. The kingdom could use its superiority, particularly in its important role in keeping the remote island connected to the outside world, to demand certain obligations on the part of Iceland, though it had difficulty in enforcing them due to the peripheral location of the island. They were never imposed by military force.

The reason why the Norwegian kingdom did not interfere to a greater extent in Iceland's domestic and external affairs, and did not attempt greater land expansion, is probably the continuous military conflicts (civil war) in which Norway was involved from around 1130 to the first decades of the $13^{\text {th }}$ century. In a brief period of calm, the kingdom attempted to have a greater say in Iceland just after 1170. King Hákon Hákonarson (Hákon gamli), who ruled Norway in 1217-63, united the kingdom and attempted to gain control over the whole Norse world which had been populated during the Viking Age. By 1240, the king could turn his attention to foreign affairs, particularly trade with England, and territorial expansion. As part of the attempt to increase trade with England, he attempted to increase his power over the Orkneys, the Hebrides, the Isle of Man and the Faroe Islands and gain control of Iceland and Greenland. He gained the support of the church and the archbishop in Trondheim. The aim was to create a Norwegian royal and ecclesiastical power (Stefánsson 1975, 139). The policy of the church was to support the king's attempts to create peace within their borders and that Icelanders, like all other subjects within these borders, should recognise the authority of the king (Jakobsson 2007, 153).

In the $13^{\text {th }}$ century, the archbishop had slowly but steadily become more influential within the Icelandic church, e.g. through the appointment of foreign bishops. Later, in the mid- $14^{\text {th }}$ century, bishops were chosen by the Pope, sometimes in consultation with the king. In the period under study, most of these bishops were of foreign origin, mainly Norwegians and Danes. The Pope and the church, in general, became more influential in Iceland, as elsewhere in Europe (Porsteinsson \& Grímsdóttir 1990, 33-39) and this was accompanied by greater foreign influence.

Many scholars have attempted to explain why Icelanders decided to become part of the Norwegian kingdom in the $13^{\text {th }}$ century. The aim of this paper is not to answer that question or evaluate these assumptions; rather, it is to evaluate whether or not the small Icelandic community followed a typical trend as defined in the small-state literature regarding alliance formation and, more precisely, by seeking shelter with a larger neighbour. In the case of Iceland, the Norwegian kingdom had always been influential in the country. At the same time as Iceland and Greenland became parts of the Norwegian kingdom, the southern part of the Norse world, the Hebrides and the Isle of Man, became parts of Scotland. Norwegian sea power north of the English Channel was in decline, due to increased competition for influence in the northern parts of the British Isles (Líndal 1974). That said, no one challenged Norwegian sea power in the North Atlantic - the northwest corner of its reach. The kingdom continued to dominate those waters for some time. Iceland's distant geographical location did not prevent the country from following a trend similar to that followed by other European countries at the time as regards the formation of dynastic and larger states. 


\section{STJÓRNSÝSLA}

To what extent the local elite regarded it as a cost to transfer authority to the king is difficult to envisage, particularly in the light of its willingness to accept royal appointments and other privileges which were of great social and economic benefit to it. Records indicate that there was considerable resistance to the crown's efforts to influence decision-making in Iceland, beginning at least as early as the conversion to Christianity and continuing throughout the Middle Ages - i.e. both before and after the formal transfer of power to the king. However, this may be related more to attempts by leading farmers and bishops to hold on to their own power and even increase their say in domestic decision-making rather than a resistance to the transfer of authority to an external actor (see, for instance, Líndal 1964). Moreover, an alignment with the kingdom secured Icelanders the right to travel in Norway and a link to the outside world. The king would guarantee 'safe travel' within the kingdom and 'regular access' to the important European markets and spiritual centres (see Figures 1, 2 and 3), while in return, Icelanders accepted certain obligations, such as his taxation and trade restrictions, at times. An alignment with the king's mission to unite the Norse world under a single ruler was, politically, regarded by some as being in Iceland's interests. It provided political shelter for the peripheral entity and temporarily stopped internal violence and dissension. Interestingly, the model in small-state literature misses the importance of shelter against domestic forces. Accordingly, the model needs to address how external actors may solve the problem of internal order.

\section{The importance of accommodation: Societal shelter?}

The first settlers in Iceland in the $9^{\text {th }}$ and $10^{\text {th }}$ centuries were of a more diverse nature than has sometimes been admitted in the past. Genetic evidence indicates an overall proportion of British Isles ancestry of about 40 per cent, with a great discrepancy between the female (62 per cent) and male (25-30 per cent) components. Hence, only about 60 per cent of the genetic origin of the present Icelandic nation was originally Scandinavian (Helgason et al. 2005 \& Helgason et al. 2009). The Norse community was spread across northwestern Europe and mixed with the local population. Norse colonies in the British Isles were suffering serious setbacks at the time of the Icelandic Settlement (Kjartansson 1996, 62). The predominantly Norse settlers brought slaves with them from these earlier-established colonies, and it was no doubt partly due to a degree of cultural assimilation in these regions that Norse culture became established as the dominant norm in Iceland. For instance, the same language, 'Viking Age Norse', was spoken in Scandinavia, the Faroe Islands, Shetland, the Orkneys and in most parts of northern Scotland. It was also spoken in various parts of England, Normandy and Ireland and in Garðaríki (the 'realm of towns') a chain of Norse settlements along the Volkhov River in Russia, as shown in Figure 4 (Líndal 1974). 
Iceland's external affairs in the Middle Ages:

Figure 4. Iceland's societal shelter: The Norse world in the $9^{\text {th }}$ and $10^{\text {th }}$ century.

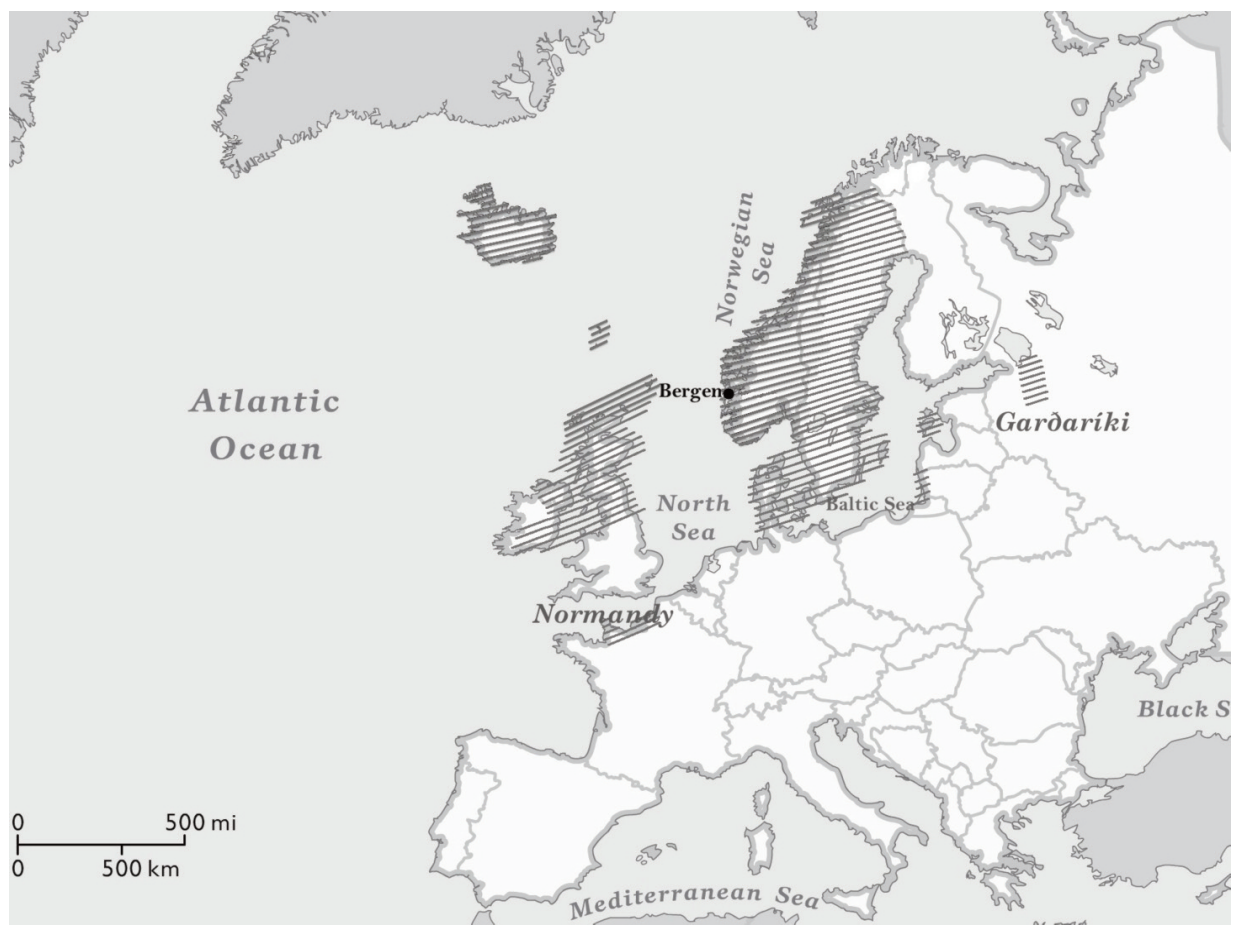

Sources: Based on numerous accounts of communication between Iceland and the outside world such as those in Porsteinsson \& Líndal 1978, 39; Le Goff 2005, 43-44.

The common language, heritage and family relations ensured the continuation of trade and cultural exchange. Mercenary services and trading had been part of the Viking/Norse expeditions (Le Goff 2005, 43) and the Settlement of Iceland has to be viewed in the context of the general Norse expansion of the period (Kjartansson 1996, 62). The Icelandic emigrants moved further on and established a permanent settlement in Greenland and attempted a settlement in Newfoundland around 1000, after Iceland is thought to have been fully populated with 15,000-30,000 inhabitants. There are great uncertainties about the exact size of the population, though it is most often estimated at 30,000 to 60,000 during the Commonwealth era and in the $14^{\text {th }}$ century (see, detailed discussion in Karlsson 2009).

Icelanders, particularly wealthy farmers and their sons, travelled widely, especially to Norway and other parts of the Norse world (and also to the Baltic Sea and France) but they did not represent the island population, or the region/country, as a group in the first half of the period under study, as has already been stated. They more likely met the Norwegian king, as they seem to have done quite often, and the kings of Denmark and Sweden, as individuals acting on their own behalf (Líndal 1974). On the other hand, Icelanders could not rely on regular communications by sea, and the 


\section{STJÓRNSÝSLA}

long distance to the island set its mark on the lifestyle and the government of the island (Porsteinsson \& Grímsdóttir 1989, 168).

Dorláksson (1979) and Karlsson (2009) argue that Iceland's trade was mainly conducted in order to increase the status of its upper class and not to ensure a supply of necessary goods for consumption or to gain profit. Rich farmers and chieftains sought extravagant foreign goods in order to distinguish themselves from the general public. Foreign trade was also important in order to serve God, i.e. external goods had to be imported to conduct divine services (one function of which was also to impress; Vésteinsson 2000, 59).

As Figure 5 demonstrates, the conversion from paganism to Christianity in the $10^{\text {th }}$ and $11^{\text {th }}$ centuries ensured a continuation of Norse influence in Iceland and also opened the country up to broader European Christian influence that was sweeping through the region from the Continent and the British Isles. First after the conversion, 'visiting bishops' sent by the Norwegian king and the archbishop tried to ensure that Iceland became more closely engaged with developments on the Continent. The conversion to Christianity made travel considerably easier, since Icelanders, like other people from the Northern countries, were no longer looked upon as pagans and hostile barbarians: they were now part of the Christian community. Christianity was an important force in establishing common customs, and was a unifying factor in Europe (Le Goff 2005).

\section{Figure 5. Iceland's societal shelter: Christianity in the $11^{\text {th }}$ and $12^{\text {th }}$ century.}

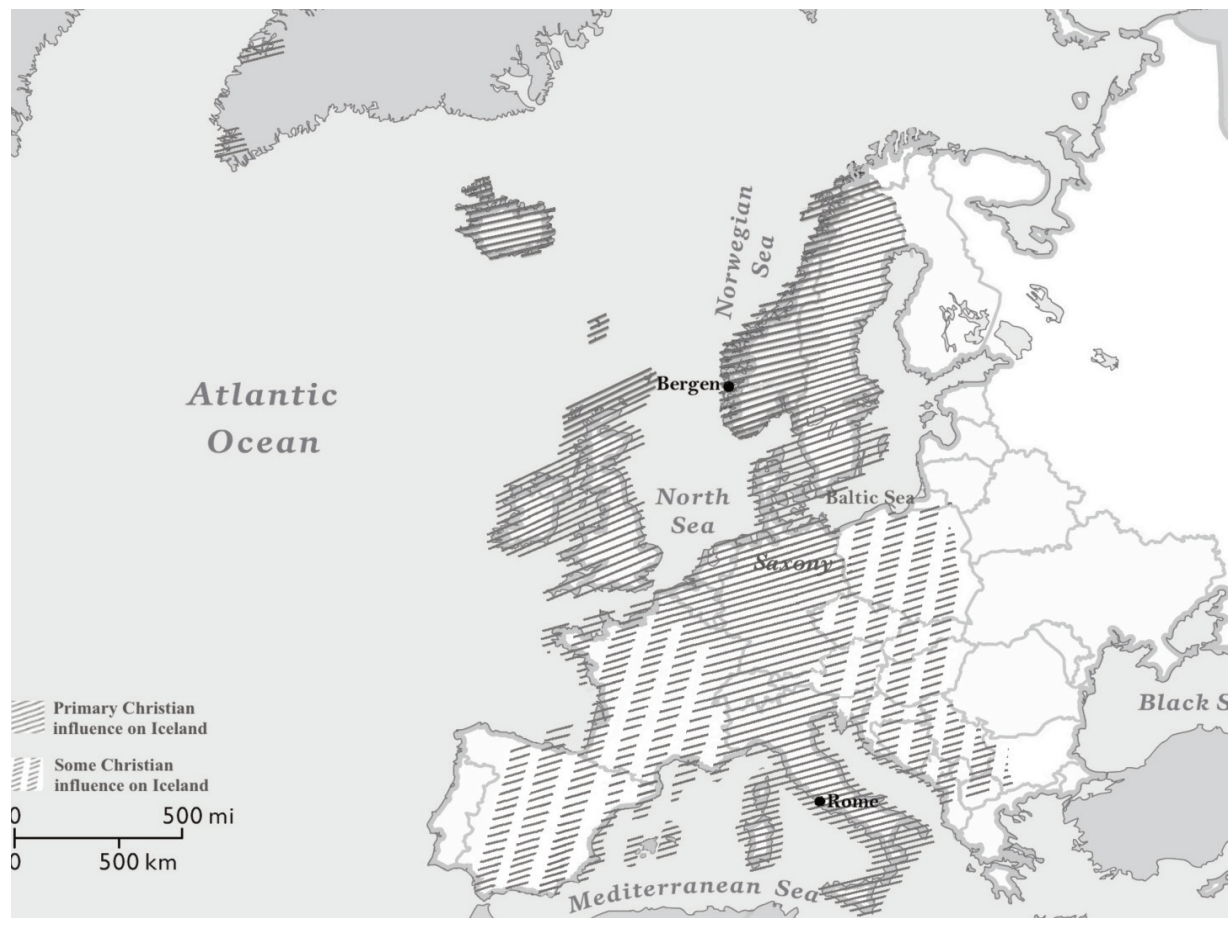

Sources: Based on numerous accounts of communication between Iceland and the outside world such as those in Le Goff 2005, 91-93. 


\section{Baldur Pórhallsson}

\section{STJÓRNMÁL \\ \& \\ STJÓRNSÝSLA}

The close connection between the regions of northwestern Europe is manifested in the broad ecclesiastical jurisdiction of the archbishop in Trondheim. This included not only Iceland but also Greenland, the Faroe Islands, the Isle of Man, the Orkneys and the Hebrides, and illustrates the cultural similarities of the inhabitants; it was the policy of the church and king that each archbishop should cover a region throughout which there was a single language and single culture. Christianity had several important effects in Iceland, as elsewhere in the Nordic region. The kings became more powerful, permanent Christian institutions were created with long-lasting effect and the career of a scholar became, for the first time, an occupation in the region. Also, the Nordic region established permanent and more extensive relations with the outside world. This southern and continental Christian influence was particularly important, since the region had been beyond the sphere of influence of the Roman Empire. Western European civilization had finally reached this northwestern outpost (see Figure 5). The $12^{\text {th }}$ century marked an inclusion in Western Christian literate civilization. Iceland now had a clergy with some Latin education and part of its elite was educated and kept in touch with European scholars (Kjartansson 1996, 66).

The pioneer figures in education in Iceland had themselves all been educated on the European continent - mostly in the same region, i.e. northwestern Germany. This may be related to the location of the archbishop over Norway and Iceland in Hamburg-Bremen and the important trade links between Iceland and Norway, on the one hand, and the German regions on the other (Líndal 1974, 255). The first Icelandic bishop was consecrated in the mid- $11^{\text {th }}$ century in Hamburg-Bremen and records indicate that, at least, the first Icelandic bishoprics ran schools (Hugason 1997). To travel to Saxony, up the river Weser, was easier than to many other parts of Europe.

This educational link provided a long-lasting connection between the Icelandic church and the Continental church. Moreover, it separated it from the English church, by which it had been influenced in the initial stages of Christianity in the country, and had since maintained some relations. Essentially, commercial exchanges between the North Sea and Baltic regions 'entailed an exchange of ideas, art objects and cultural influences’ (Brand \& Müller 2007, 7), as shown in Figure 6. This was nowhere more visible than in the ports (Brand \& Müller 2007, 7), such as Bergen. Iceland became part of this picture through the city and its trade with the Baltic Sea. 


\section{STJÓRNSÝSLA}

Figure 6. Iceland's societal shelter: Trading areas served by the Hanseatic League and England in the $13^{\text {th }}$ and $14^{\text {th }}$ century.

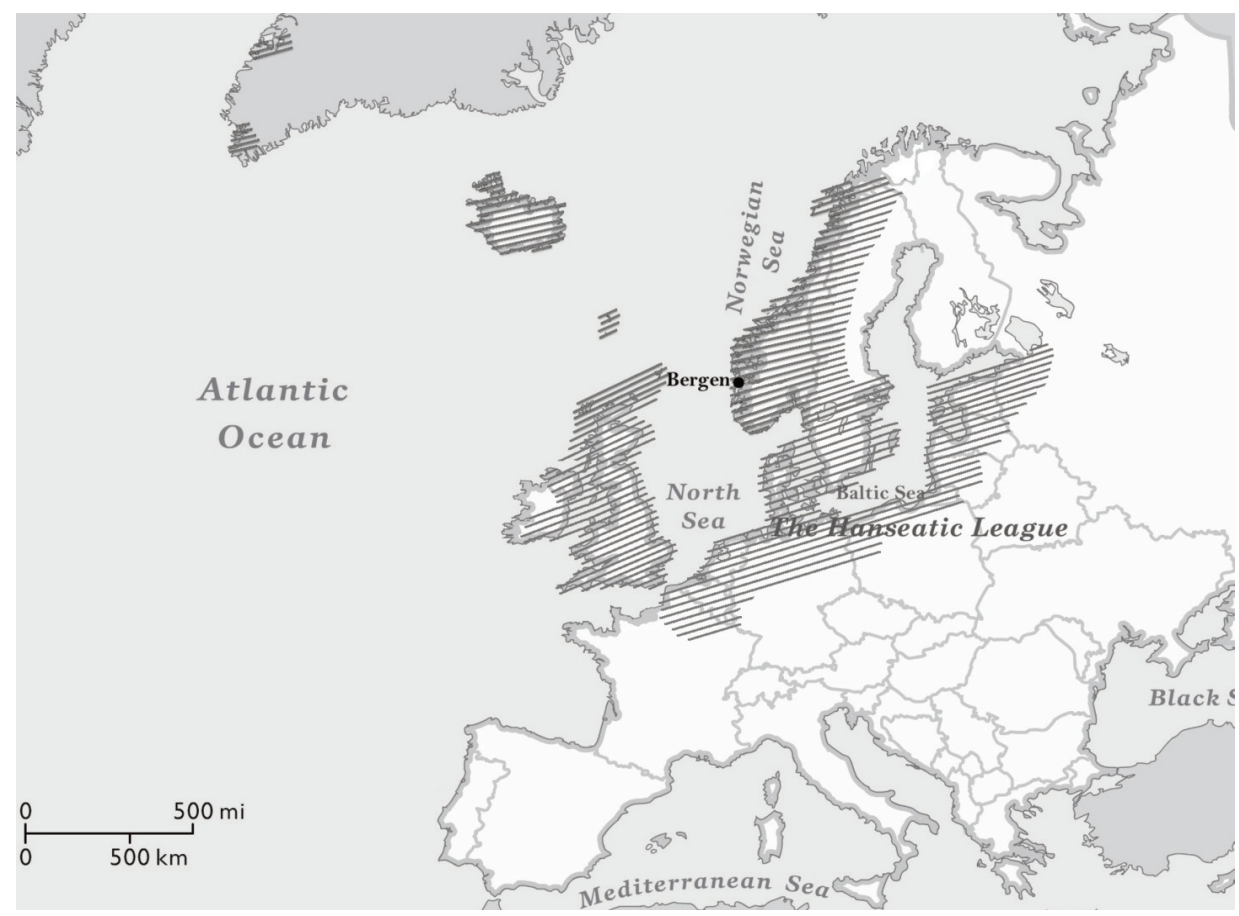

Sources: Based on numerous accounts of communication between Iceland and the outside world such as those in Porsteinsson \& Grímsdóttir 1989; Porláksson 1991.

Jakobsson (2009) argues that, during the Middle Ages, Icelanders regarded foreign travel as having three main purposes and benefits: association with noble men, adaptation to their manners and bringing back tokens of this adaptation. Travel had an important educational dimension, i.e. a visit to noble men and learning their manners was regarded as an education in itself (Jakobsson 2009). He argues that descriptions of these travels reflect the dichotomy of Icelanders' home base on the periphery and their spiritual centre in the Mediterranean, after the conversion to Christianity: 'The view that a culture normally regards itself as the world's centre does not hold true for Iceland during the Middle Ages' (Jakobsson 2009, 923). Icelanders saw themselves as 'belonging to a larger unity with all its benefits and constraints, the most important drawback being that Iceland was seen as peripheral. ... The distance of Iceland from the political, cultural and economic centres had to be compensated for' (Jakobsson 2009, 923). During the Commonwealth era, trade was probably mainly conducted to serve social purposes along with the economic aims of the elite (Hjaltalín 2004, 222; Júlíusson 2007, 6).

Furthermore, and importantly, the development of Icelandic literature (the Sagas, 


\section{Baldur pórhallsson}

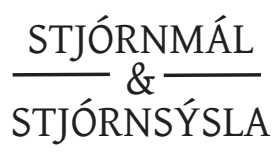

the Legendary Sagas and Sagas of Chivalry) followed the developmental trends in European literature throughout our period under study. This indicates a substantial and lasting link with educational centres in Europe - despite the peripheral location of the country. Without their influences, Icelanders would not have been able to write their notable works. Importantly, the Icelandic scribes had customers abroad and, thus, their work became a part of the islanders' export. Also, Icelandic schools seem to have been under strong external influence and taught subjects similar to those taught elsewhere in Europe (Kristjánsson 1975, 147-221). From the Settlement up to the $14^{\text {th }}$ century, there existed close literary ties between Iceland and Norway. From the beginning, Icelandic skalds were frequent visitors at Norwegian courts; later, Icelandic writers would export their written works to Norway and, in the $14^{\text {th }}$ century, Icelandic scribes frequently copied sagas for export to Norway: 'Written texts and literary influences thus flowed freely between the countries' (Kjartansson 1996, 75). Moreover, art work on the island, which was mainly Nordic and partly Celtic, in the beginning, took shape, with Christianity, under influence from traditions from all over Europe (east, west and south) - not from any single area in particular (Björnsson 1975, 281). As Figures 4, 5 and 6 show, Iceland was not at the centre of Europe but could not escape its highway of cultural transfer.

Records indicate that the local Icelandic elite was very much concerned with keeping in contact with its counterparts and noble men in the Norse world and its surroundings throughout the period under study. It was eager to adapt to their way of life and receive the same status and privileges. Societal engagement through reliable shipping contact was essential in order to accomplish these aims. Securing regular exchanges with the outside world was an essential part of keeping in touch with developments in other parts of the Norse and Christian world. Securing societal shelter may have been an important feature of external affairs during the Middle Ages.

\section{Conclusion}

Small states form alliances in order to compensate for their lack of defence capabilities and economic dependence, according to the literature. Geographical location is of importance, since the nearer a small state is to a great power and potential confrontations in the international system, the more it is in need of an ally. The small-state literature and its alliance and shelter concepts do not, in general, take into account the importance of cultural communication and social interaction between states. Our analysis raises the question whether peripheral geographical location may, in fact, impose pressure on a small entity to engage in close relations with its closest neighbours in order to maintain social engagement of the inhabitants with the outside world. Social engagement with 'outsiders' will happen automatically in centrally located small entities, such as in the Medieval European city-states. This is not the case with remote entities. They have to take precautions if they are not to be left isolated. Isolation will, at least, have considerable impact on the entities' elites, i.e. their living standards, socialization, cultural communication and education. 


\section{STJÓRNSÝSLA}

Aspects of alliance formation based on potential military threats and economic vulnerability may, in general, hold true. The latter is the case with Iceland in the Middle Ages. The important question is whether social engagement is also a vital part of the explanation of why Icelanders were willing to accept royal demands and favours and seek the shelter of the Norwegian crown. Hence, the local elite's aim may not only have been to guarantee regular shipping to the country in order to enhance its living standard as a result of the benefits of external trade but also to engage in closer social relations with the outside world and gain domestic political power for itself. External social engagement could include simple things like the exchange of communication and the adoption of life-styles, and more importantly, the acquisition of status and privileges both at home and abroad. Accordingly, the relationship with Norway provided societal shelter - at least for the wealthy chieftains and farmers alongside economic shelter.

The case of Iceland fits perfectly into the picture of a vulnerable small economy during the Middle Ages, and Rokkan and Urwin's three types of transitions which construct the centre-periphery relations model in how the periphery is dependent upon the centre, i.e. concerning economy, politics and culture. Moreover, their three key characteristics of peripheries which distinguish them from the centre (distance, difference and dependence) place Icelandic-Norwegian relations in a new light. Iceland's distance from Norway partly determined the structure of its economy (e.g. as regards export products and trade) and the difficulties associated with the crown's attempts to control the island. The long distance between the countries/regions made cultural communication more difficult and may explain the creation of a form of a separate identity in Iceland - though it is remarkable how closely Iceland followed political and societal developments on the European continent and the British Isles. Cultural influence depended on the link with the Norse world. Also, Iceland's economy and living standards, or at least those of the elite, may have undergone distinct cycles depending on external trade relations with the outside world and the development of the Norwegian economy at any given time.

Medieval communities had to deal with threats and risks just as modern states do, though these were present in different proportions and were of a somewhat different nature. This is the case with the traditional threats identified in the literature on international relations, i.e. regarding military, economic and natural-hazard risks. The small peripheral Icelandic community was particularly exposed to serious disturbances in transport logistics. Icelanders needed external materials of various types, including timber for boats to enable them to utilize their fish stocks. Hence, the NorwegianIcelandic transport link provided the island with important economic shelter and general economic viability - at least for the community's leaders. Norwegian sea power provided Iceland with access to an external market, i.e. first the common Norse market and, later, the Hansa and British markets.

In political shelter terms, the island was too remote to be dragged into military conflicts between its neighbouring countries during the Middle Ages and, thus, was not in need of military backing for its own defences. This limited the risk involved in 


\section{Baldur pórhallsson}

\section{STJÓRNSÝSLA}

its association with Norway and later as regards the formation of the state. Also, the remoteness of the island made it more difficult for the Norwegian kingdom to exercise its power within its boundaries, though the king is regarded as having used great political pressure to get his way in Iceland. The civil war was suspended as Icelanders submitted to the Norwegian king (though internal conflicts continued to occur according to Porláksson 2000) - which entailed the creation of an executive branch of government - and, thus provided protection for the community at large. Hence, the model in the small state literature needs to address how external actors may solve the problem of internal order.

Transfer of formal political authority from Icelanders to the Norwegian king can be regarded as a political cost according to the model. This is also the case with Norwegian taxation on trade, shipping communications and domestic production and the crown's trade restrictions, i.e. these things were economic costs. The analysis of the need for shelter needs to address the 'realpolitik' consideration that certain political and economic costs may be involved in receiving shelter from a larger country (for further discussion, see Bailes and Pórhallsson 2012). On the other hand, it should not necessarily be regarded a cost to adopt the rule and norms of the protector. Our case indicates that a small entity may, at times, be eager to adopt the protector's customs and perceive submission to external rule as less costly than the current situation or even as leading to outright benefits for the community, at large, or for the local elite.

The shelter provided by Norwegian sea power did not start to crumble until Denmark took charge within the new kingdom due to its better location regarding the Baltic Sea trade of the Hanseatic League. Also, the Danes outnumbered the Norwegian and Swedish populations combined, and were richer. Norway slowly became peripheral as from the late $14^{\text {th }}$ century (Porsteinsson \& Grímsdóttir 1989, 217). Norwegian sea power never regained its former glory. Importantly, for Iceland, a new North Atlantic sea power emerged: England, from which shipping to Iceland began, most likely, in the last decade of the $14^{\text {th }}$ century.

\section{Notes}

1 The beginning of the Viking Age is often dated to the raid on the Lindisfarne Monastery off the northeast coast of England in 793 (Líndal 1974, 228).

2 In her work Boulhosa (2005) has argued that the Old Covenant was a later fabrication, written down by the Icelandic authorities in the 15th century, at a time when they were under severe economical and political pressures. The Old Covenant, according to Boulhosa, was supposed to better enable them to negotiate with the Norwegian crown in the 15th century. The evidence cited in her analysis has been contested by some Icelandic historians (Kjartansson 2011; porláksson 2006) who find her results somewhat misleading and argue that her work might not be as original as, for example, Jónsson (2006) thinks. Nevertheless, it is generally agreed that her work calls for further research on the origin and purpose of the Old Covenant.

3 For instance, Icelanders took part in the first Crusade in 1096 and the siege of Nicaea a year later, according to a French poem 'Chanson d'Antioche' (Líndal 1974, 210). 


\section{References}

Aðils, J. J. (1903). Íslenzkt pjóderni. Alpýdufyrirlestrar. Reykjavík: Sigfús Eymundsson.

Aðils, J. J. (1915). Íslandssaga. Reykjavík: Bókaverzlun Sigf. Eymundssonar.

Agnarsdóttir, A. (1995). “Er Íslandssagan einangruð?”, Saga XXXIII, 68-76.

Alesina, A. \& Spolaore, E. (2005). The Size of Nations. Cambridge: The MIT Press.

Archer, C. \& Nugent, N. (2002). "Small states and the European Union", Current politics and economics of Europe 11(1): 1 - 10.

Bailes, A. J. K. \& Pórhallsson, B. (2012). "Instrumentalizing the European Union in Small State Strategies", Journal of European Integration (forthcoming).

Bairoch, P. (1989). "The paradoxes of economic history - Economic laws and history", European Economic Review 33, 225-249.

Baker Fox, A. (1959). The power of small states. Diplomacy in World War II. Chicago: The University of Chicago Press.

Björnsson, B. P. (1975). "Myndlistarsaga”, in S. Líndal (ed.) Saga Íslands II. Reykjavík: Hið íslenzka bókmenntafélag.

Björnsson, S., Gronfeldt, S., Oddsson, F., Ólafsson, J. K., Eyjólfsson, M., \& Konráðsdóttir, S. (2008, March). Ímynd Íslands: Styrkur, staða og stefna. Reykjavík: Prime Minister's Office.

Boulhosa, P. P. (2005). Icelanders and the Kings of Norway: Mediaeval Sagas and Legal Texts. Leiden: Brill.

Brand, H. \& Müller, L. (2007). "Introduction”, in H. Brand. \& L. Müller (eds.) The Dynamics of Economic Culture in the North Sea and Baltic Region in the Late Middle Ages and Early Modern Period. Hilversum: Uitgeverij Verloren.

Briguglio, L., Cordina, G. \& Kisanga, E. J. (eds.) (2006). Building the Economic Resilience of Fragile States. Malta: Formatek Publishing for the Islands and Small States Institute of the University of Malta and the Commonwealth Secretariat, London.

Cooper, A. F. \& Shaw, T. M. (eds.) (2009). The Diplomacies of Small States: Between Vulnerability and Resilience. England: Palgrave Macmillan.

Eggertsson, D. (1996). "No experiments, monumental disasters: Why it took a thousand years to develop a specialized fishing industry in Iceland", Journal of Economic Behavior and Organisation 30, 1-23.

Gade, J.A. (1951). The Hanseatic control of Norwegian commerce during the late Middle Ages. Leiden: E.J. Brill.

Galasso, V. N. (2012). "Honor and The Performance of Roman State Identity", Foreign Policy Analysis 8(2): 173-189.

Goodacre, S., Helgason, A., Nicholson, J., Southam, L., Ferguson, L., Hickey, E., Vega, E., Stefánsson, K., Ward, R. \& Sykes, B. (2005). "Genetic evidence for a family-based Scandinavian settlement of Shetland and Orkney during the Viking periods”, Heredity 95, 129-135.

Guðmundsson, H. (2002). Land úr landi: Greinar. Reykjavík: Háskólaútgáfan.

Gunnarsson, G. (1980). A Study of Casual Relations in Climate and History. Lund: EkonomiskHistoriska Institutionen.

Gunnarsson, G. (1987). Upp er boðið Ísaland. Einokunarverslun og islensket samfélag 1602-1787. Reykjavík: Örn og Örlygur.

Handel, M. (1981). Weak States in the International System. London: Frank Cass.

Hálfdanarson, G. (2001a). Íslenska pjóơríkið - uppruni og endimörk. Reykjavík: Hið íslenska bókmenntafélag \& Reykjavíkur Akademían.

Hálfdanarson, G. (2001b). "Gamli sáttmáli: frumsamningur íslensks ríkisvalds”, in G. Gíslason (ed.) Lindala: Sigurơur Lindal sjötugur 2. júli 2001. Reykjavík: Hið íslenska bókmenntafélag, 181-194.

Helgason, A., Goodacre, Nicholson, S., Southam, L., Ferguson, L., Hickey, E., Vega, E., Stefánsson, K., Ward, R. \& Sykes, B. (2005). "Genetic evidence for a family-based Scandinavian settlement of Shetland and Orkney during the Viking periods", Heredity 95, 129-135.

Helgason, A., Lalueza-Fox, C., Ghosh, S., Sigurðardóttir, S., Sampietro, M. L., Gigli, E., Baker, A., Bertranpetit, J., Árnadóttir, L., Dorsteinsdottir, U., Stefánsson, K. (2009). "Sequences From First 
Iceland's external affairs in the Middle Ages:

The shelter of Norwegian sea power

\section{Baldur pórhallsson}

\section{STJÓRNMÁL

Settlers Reveal Rapid Evolution in Icelandic mtDNA Pool”, PLoS Genet 5(1).

Hjaltalín, P. (2004). "Vöruframboð og verslunartengsl: Viðskipti á miðöldum”, in Á. Björnsson \& H. Róbertsdóttir (eds.), Hlutavelta tímans: Menningararfur á pjódminjasafni. Reykjavík: Pjóðminjasafn Íslands, 214-223.

Hugason, H. (1997). "Kristni og kirkja”, in P. Helgason \& S. Jakobsson (eds.) Saga Nordurlanda 13971997: 10 ritgerdir. Copenhagen: DR Multimedie.

Ingimundarson, V. (2007). “Eftir „bandarísku öldina“: Samstarf Íslands við aðrar Evrópupjóðir í öryggismálum”, in S. B. Ómarsdóttir (ed.) Ný staða Íslands i utanríkismálum: Tengsl við önnur Evrópulönd. Reykjavík: Alpjóðamálastofnun, 153-163.

Jakobsson, S. (2005). Við og veröldin: Heimsmynd Íslendinga 1100-1400. Reykjavík: Háskólaútgáfan.

Jakobsson, S. (2007). "Pegar Ísland varð hluti af Noregi: Hugleiðing um valkosti sögunnar”, Skirnir, vor, 181, 151-166.

Jakobsson, S. (2009). "Centre and Periphery in Icelandic Medieval Discourse”, in A. Ney, H. Williams \& F. C. Ljungquist (eds.) A austrvega: Saga and East Scandinavia: preprint papers of The $14^{\text {th }}$ International Saga Conference, Uppsala, 9 ${ }^{\text {th }}-15^{\text {th }}$ August, 2009, II. Gravle: Gavle University Press, 918-924.

Jóhannesson, J. (1974). A History of the Icelandic Commonwealth, translated by H. Bessason. Winnipeg: University of Manitoba Press. .

Jóhannesson, P. (1965). 'Um atvinnu- og fjárhagi á Íslandi á 14. og 15. öld'. “Atvinnuhagir á Íslandi fram um siðaskipti“. Lýdir og landshagir I, 9-67.

Jónsson, H. (1989). Íslensk sjálfstaðis- og utanríkismál frá landnámi til vorra daga. Reykjavík: Félagsmálastofnunin.

Jónsson, J. (1915-1916). Íslandssaga handa börnum II. Reykjavík.

Jónsson, M. (2006). “Efasemdir um sáttmála Íslendinga og Noregskonungs árið 1262”, in B.

Eypórsson \& H. Lárusson (eds.) Pridja islenska sögupingið 18.-21. mai 2006 - Rádstefnurit. Reykjavík: Aðstandendur Priðja íslenska sögupingsins, 399-406.

Júlíusson, A. D. (2007). "Peasants, aristocracy and state power in Iceland 1400-1650", The CAHD Papers 2007-2, available at http:/ / axelkrist.com/CAHD/papers.html, accessed 29 May 2012.

Karlsson, G. (1975). "Frá pjóðveldi til konungsríkis”, in S. Líndal (ed.) Saga Íslands II. Reykjavík: Hið íslenzka bókmenntafélag.

Karlsson, G. (1985). Sjálfstæðði Íslendinga 1 - Kennslutillögur. Reykjavík: Námsgagnastofnun.

Karlsson, G. (1989). Samband við miðaldir. Reykjavík: Mál og menning.

Karlsson, G. (2000). Iceland's 1100 Years. The History of a Marginal Society. London: C. Hurst.

Karlsson, G. (2009). Lifsbjörg Íslendinga frá 10. öld til 16. aldar-Handbók i islenskri miðaldasögu III. Reykjavík: Háskólaútgáfan.

Katzenstein, P. (1984). Corporatism and Change: Austria, Switzerland, and the Politics of Industry. Ithaca; London: Cornell University Press.

Katzenstein, P. (1985). Small States in World Markets: Industrial Policy in Europe. Ithaca; London: Cornell University Press.

Keohane, R. O. (1969). “Lilliputians' dilemmas: Small states in international politics”, International Organization 23(2): 291-310.

Kjartansson, H. S. (1996). "History and Culture", in Nordal, J. \& Kristinsson, V. (eds). Iceland: The Republic. Reykjavík: The Central Bank of Iceland.

Kjartansson, H. S. (2011). “Gamli sáttmáli - hvað næst?”, Saga XLIX(1): 133-153.

Kristjánsson, J. (1975). “Bókmenntasaga”, in S. Líndal (ed.) Saga Íslands II. Reykjavík: Hið íslenzka bókmenntafélag.

Kristjánsson, L. (1980). Íslenækir sjávarhattir I. Reykjavík: Menningarsjóður.

Le Goff, J. (2005). The Birth of Europe, translated by J. Lloyd. Malden; Oxford; Carlton: Blackwell Publishing.

Leira, H. \& Neumann, I. B. (2007). "Consular representation in an emerging state: The case of Norway", Occasional Paper 2007-1, available at

http://stofnanir.hi.is/ams/sites/files/ams/Consular\%20representation3.pdf, accessed 1 June 2012. 
Líndal, S. (1964). “Utanríkisstefna Íslendinga á 13. öld og aðdragandi sáttmálans 1262-64”, Úlfljótur XVII(1): 5-36.

Líndal, S. (1974). "Ísland og umheimurinn”, in S. Líndal (ed.) Saga Íslands I. Reykjavík: Hið íslenzka bókmenntafélag.

Neumann, I. B. (1994). "A Region-Building Approach to Northern Europe”, Review of International Studies, 20(1): 53-74.

Neumann, I. B. and Gstöhl, S. (2004). "Lilliputians in Gulliver's World? Small states in international relations", available at http://www3.hi.is/solofile/1008303, accessed 26 May 2009.

Nielssen, A. R. (2001). "Indigenous and Early Fisheries in North-Norway", in F. Petrucci (ed.) The Sea in European History. Pisa: University of Pisa, 185-184.

Nordal, J. \& Kristinsson, V. (eds) (1996). Iceland: The Republic. Reykjavík: The Central Bank of Iceland.

Oxford Analytica. (2010, 25 August). "Europe: Small states prefer partial EU integration”, Oxford Strategic Analysis. Oxford: Oxford Analytica.

Pasquinucci, M. (2002). "City-States and Roman Administration: from the Conquest of Latium to the Empire", in F. Petrucci (ed.) Empires and States in European Perspective. Pisa: Edizioni Plus University of Pisa.

Reus-Smit, C. (1999). The Moral Purpose of the State: Culture, Social Identity, and Institutional Rationality in international relations. Princeton, New Jersey: Princeton University Press.

Rokkan, S. \& Urwin D. W. (1983). Economy, Territory, Identity: Politics of West European Peripheries. London, USA, New Delhi: Sage Publications.

Salvatori, E. (2002). "Pisa in the Middle Ages: the Dream and the Reality of Empire", in F. Petrucci (ed.) Empires and States in European Perspective. Pisa: Edizioni Plus - University of Pisa.

Schwartz, H. (2011). "Iceland's Financial Iceberg: Why Leveraging Up is a Titanic Mistake without a Reserve Currency”, European political Science, Symposium 10(3): 292-301.

Sheehan, M. (2005). International SECURITY: An Analytical Survey. USA: Lynne Rienner Publishers.

Sigurðsson, J. V. (2000). "Allir sem sjá líta pó ekki jafnt á: Sagnaritun um íslenskar miðaldir fram um 1300”, Saga XXXVIII, 33-57.

Stabel, P. (2001). "Bruges and the German Hanse: Brokering European Commerce", in F. Petrucci (ed.) The Sea in European History. Pisa: University of Pisa, 35-55.

Stefánsson, M. (1975). "Kirkjuvald eflist”, in S. Líndal (ed.) Saga Íslands II. Reykjavík: Hið íslenzka bókmenntafélag.

Thoroddsen, P. (1924). “Saga fiskveiðanna við Ísland”, in P. Thoroddsen (ed.) Safn freðafjelagsins um Ísland og Íslendinga, III (fjórar ritgjöðir). Copenhagen: Hið íslenska fræðafélag í Kaupmannahöfn.

Vésteinsson, O. (2000). The Christianization of Iceland: Priests, Power and Social Change 1000-1300. Oxford: Oxford University Press.

Vésteinsson, O. (2005). "Smá-saga: Um nýlegar rannsóknir í íslenskum miðaldafræðum”, Ritið 5(3): 159-178.

Vital, D. (1967). The Inequality of States: A Study of the Small Power in International Relations. Oxford: Clarendon Press.

Pór, J. P. (2002). Sjósókn og sjávarfang: Saga sjávarútvegs á Íslandi I - Árabáta- og skútuöld. Akureyri: Bókaútgáfan Hólar.

Pórhallsson, B. (2011). "Domestic buffer versus external shelter: viability of small states in the new globalised economy”, European Political Science, Symposium 10(3): 324-336.

porláksson, H. (1979). "Snorri Sturluson og Oddaverjar", in G. Karlsson \& H. Porláksson (eds.) Snorri, átta alda minning. Reykjavík: Sögufélag, 53-88.

porláksson, H. (1991). Vadmál og verðlag. Vadmál i utanlandsvidskiptum og búskap Íslendinga á 13. og 14. öld. Reykjavík.

Porláksson, H. (2000). “Sagnfræði um Íslandssögu á tímabilinu 1300-1550”, Saga XXXVIII, 59-81.

porláksson, H. (2001). “Íslensk skreið skákar norskri”, in G. Gíslason (ed.) Lindala: Sigurður Lindal sjötugur 2. júli 2001. Reykjavík: Hið íslenska bókmenntafélag, 265-293.

porláksson, H. (2003) “Fiskur og höfðingar á Vestfjörðum”, Ársrit sögufélags Ísfirơinga 43. 
Iceland's external affairs in the Middle Ages:

The shelter of Norwegian sea power

\section{Baldur pórhallsson}

\section{STJÓRNMÁL \\ $\&$ \\ STJÓRNSÝSLA}

Dorláksson, H. (2003). "Frá kirkjuvaldi til ríkisvalds", in S. Líndal (ed.) Saga Íslands VI. Reykjavík: Hið íslenzka bókmenntafélag.

Dorláksson, H. (2006). "Er Gamli sáttmáli tómur tilbúningur?”, in B. Eypórsson \& H. Lárusson (eds.) Driðja islenska sögupingið 18.-21. mai 2006 - Rádstefnurit. Reykjavík: Aðstandendur Priðja íslenska sögupingsins, 392-398.

Porsteinsson, B. (1964). "Pættir úr verzlunarsögu. Nokkur atriði úr norskri verzlunarsögu fyrir 1350", Saga IV, 3-52.

porsteinsson, B. (1966). Ný Íslandssaga: Djódveldisöld. Reykjavík: Heimskringla.

porsteinsson, B. \& Grímsdóttir G. A. (1989). "Norska öldin”, in S. Líndal (ed.) Saga Íslands IV.

Reykjavík: Hið íslenzka bókmenntafélag.

porsteinsson, B. \& Grímsdóttir G. A. (1990). "Enska öldin”, in S. Líndal (ed.) Saga Íslands V.

Reykjavík: Hið íslenzka bókmenntafélag.

porsteinsson, B. \& Jónsson, B. (1991). Íslandssaga til okkear daga. Reykjavík: Sögufélag.

porsteinsson, B. \& Líndal S. (1978) "Lögfesting konungsvalds", in S. Líndal (ed.) Saga Íslands III.

Reykjavík: Hið íslenzka bókmenntafélag. 
